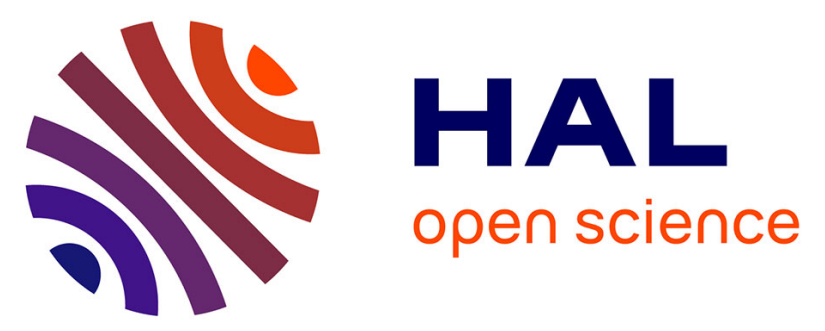

\title{
Atom Transfer Radical Addition Catalyzed by Ruthenium-Arene Complexes Bearing a Hybrid Phosphine-Diene Ligand
}

Florian Chotard, Raluca Malacea-Kabbara, Cédric Balan, Ewen Bodio, Michel Picquet, Philippe Richard, Miguel Ponce-Vargas, Paul Fleurat-Lessard, Pierre Le Gendre

\section{To cite this version:}

Florian Chotard, Raluca Malacea-Kabbara, Cédric Balan, Ewen Bodio, Michel Picquet, et al.. Atom Transfer Radical Addition Catalyzed by Ruthenium-Arene Complexes Bearing a Hybrid PhosphineDiene Ligand. Organometallics, 2018, 37 (5), pp.812 - 820. 10.1021/acs.organomet.7b00851 . hal01857060

\author{
HAL Id: hal-01857060 \\ https://u-bourgogne.hal.science/hal-01857060
}

Submitted on 6 Dec 2021

HAL is a multi-disciplinary open access archive for the deposit and dissemination of scientific research documents, whether they are published or not. The documents may come from teaching and research institutions in France or abroad, or from public or private research centers.
L'archive ouverte pluridisciplinaire HAL, est destinée au dépôt et à la diffusion de documents scientifiques de niveau recherche, publiés ou non, émanant des établissements d'enseignement et de recherche français ou étrangers, des laboratoires publics ou privés. 


\title{
Atom Transfer Radical Addition catalysed by Ruthenium-Arene Complexes bearing a Hybrid Phosphine-Diene Ligand.
}

\author{
Florian Chotard, Raluca Malacea-Kabbara,* Cédric Balan, Ewen Bodio, Michel Picquet, Philippe Ri- \\ chard, Miguel Ponce-Vargas, Paul Fleurat-Lessard and Pierre Le Gendre*
}

Institut de Chimie Moléculaire de l'Université de Bourgogne (ICMUB), Université de Bourgogne Franche-Comté (UMR 6302), 9, av. A. Savary, 21078 Dijon, France.

\section{Supporting Information}

\begin{abstract}
The synthesis and characterization of a series of arene ruthenium complexes bearing either (3,5-cycloheptadienyl)diphenylphosphine or (cycloheptyl)diphenylphosphine are reported. Upon irradiation or heating, all these complexes lose their arene ligand but then exhibit a different behavior depending on the nature of the phosphine ligand. (Cycloheptadienyl)phosphine complexes $\mathbf{1}$ and $\mathbf{3}$ give a cationic dinuclear Ru complex $\mathbf{5}$ for which the two Ru atoms are bridged by three chlorido ligands and flanked by two tridendate (cycloheptadienyl)phosphines. (Cycloheptyl)diphenylphosphine complexes $\mathbf{2}$ and $\mathbf{4}$ undergo arene exchange when toluene is used as solvent or degrade in dichloromethane. ATRA catalytic trials conducted in parallel with these complexes using $\mathrm{CCl}_{4}$ and styrene as standard substrates, highlighted the deep impact of the dienyl moiety on the results. In smooth conditions (UV irradiation or moderate heating), only (cycloheptyl)phosphine derivatives give Karasch adduct in satisfactory yields. Their performance was considerably improved by combining irradiation and heating. At higher temperature, the cationic dinuclear complex 5 revealed as active and robust, giving turnover numbers as high as 9700 when tetradecene and $\mathrm{CCl}_{4}$ were used as substrates.
\end{abstract}

\section{INTRODUCTION}

$\left[\mathrm{RuCl}_{2}\right.$ (arene) $\left.\left(\mathrm{PR}_{3}\right)\right]$ complexes are known for promoting a great variety of catalytic transformations, ${ }^{1}$ among which Atom Transfer Radical Addition (ATRA). ${ }^{2}$ This reaction, also called Kharasch addition, allows the addition of a polyhalogenated substrate to an olefin in a controlled manner. ${ }^{3,4}$ (Arene) $\mathrm{RuCl}_{2}\left(\mathrm{PR}_{3}\right)$ complexes are readily available and air-stable. ${ }^{5}$ They can be activated by irradiation or simple heating which results in the loss of the arene ligand. ${ }^{6,7}$ These precatalysts are thus particularly attractive from a practical point of view. Main drawbacks are their relatively moderate activity in ATRA with respect to the best $\mathrm{Ru}$ systems described to date, ${ }^{8,9}$ and their propensity to degrade upon prolonged reaction time, thus limiting the turnover number (TON). The recurrent problem of stability met with these catalysts may be explained by the highly coordinatively unsatured nature of the active species formed once the $6 \pi$-electrons-arene ligand is released. Chelated $\mathrm{Ru}$ complexes with phosphine-arene ligands have been designed to address this issue. Unfortunately, they were found inefficient for promoting mechanistically related Atom Transfer Radical Polymerisation (ATRP) reactions due to their too high intertness. ${ }^{10} \mathrm{We}$ hypothesized that the use of hybrid phosphinediene ligand instead might be a good compromise: it should give stable but still active catalyst for ATRA reaction. First set of catalytic trials were done using a ( $p$-cymene) Ru complex containing a phosphine with a pendant 1,3-butadiene moiety. ${ }^{11,12}$ Some interesting results were obtained for the ATRA reaction. However, all our efforts, at that time, to isolate, characterize or even detect a chelated phosphine-diene complex failed. Thus, we were unable to prove our concept. We therefore decided to use (3,5-cycloheptadienyl)diphenylphosphine in $\mathrm{Ru}$ promoted ATRA reaction since we previously clearly established the chelating abilities of this hybrid phosphine diene ligand with rhodium. ${ }^{13}$ Herein, we present the synthesis of ( $p$-cymene) $\mathrm{Ru}$ complex $\mathbf{1}$ with cycloheptadienylphosphine ligand (Figure 1). For the sake of comparison, we describe the synthesis of Ru complex 2 with (cycloheptyl)diphenylphosphine ligand. This provides an exact analogue of complex $\mathbf{1}$ which allows to estimate the contribution of the dienyl moiety while avoiding other electronic and steric features of the ligand. Since the catalytic activity results from the arene release, we also targeted Ru complexes $3, \mathbf{4}$ with more labile electron poor ethyl benzoate ligand. Efforts toward the identification of the species formed upon arene disengagement are described as well as assessment of the catalytic performance of these complexes in ATRA.
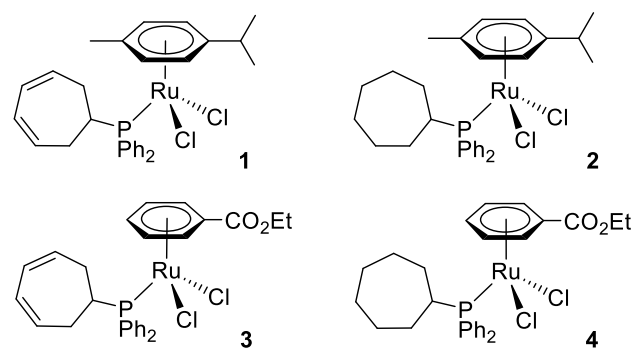

Figure 1: Ruthenium complexes with cycloheptadienyl- or cycloheptylphosphine ligands 


\section{RESULTS AND DISCUSSION}

(3,5-Cycloheptadienyl)diphenylphosphine has been obtained via the catalytic hydrophosphination of 1,3,5-cycloheptatriene with diphenylphosphine in the presence of $n$-BuLi according to our previously described procedure. ${ }^{14}$ Its saturated analogue was synthesized by reaction of bromocycloheptane with lithium diphenylphosphide in diethyl ether at room temperature. The (cycloheptyl)phosphine was obtained as a white powder in $94 \%$ yield. The synthesis of the Ru complexes 1-4 was then accomplished by reacting the cycloheptadienyl- or cycloheptylphosphine with 0.5 equiv. of the respective dimer $\left[\mathrm{Ru}\left(\eta^{6}-\right.\right.$ arene) $\left.\mathrm{Cl}_{2}\right]_{2}$ (yields range between 90 and $95 \%$ ). The complexes 1-4 were fully characterized by $1 \mathrm{D} \mathrm{NMR}\left({ }^{1} \mathrm{H},{ }^{13} \mathrm{C},{ }^{31} \mathrm{P}\right), 2 \mathrm{D}$ NMR (COSY, HSQC, HMBC), Elemental Analysis, HRMS and IR spectroscopy. The ${ }^{31} \mathrm{P}$ NMR spectra of complexes 1-4 show one singlet at 21.3, 23.7, 25.4 and 27.7 ppm, respectively, downfield shifted of either 25 or 30 ppm relatively to free phosphine depending on the arene ligand. The ${ }^{1} \mathrm{H}$ NMR spectra of 1 and 3 display only one multiplet between 5.68 and $5.80 \mathrm{ppm}$ for the four protons of the dienyl part, with the same shape and in the same chemical shift range as the free ligand. These results are indicative of the coordination of the phosphorus atoms to the ruthenium metal and of the non-coordinated state of the dienyl part of the (cycloheptadienyl)phosphine. Suitable crystals for X-Ray diffraction studies of complexes 1-4 were obtained by vapour diffusion techniques. ORTEP views of complexes 1-4 are presented in Figure 2.
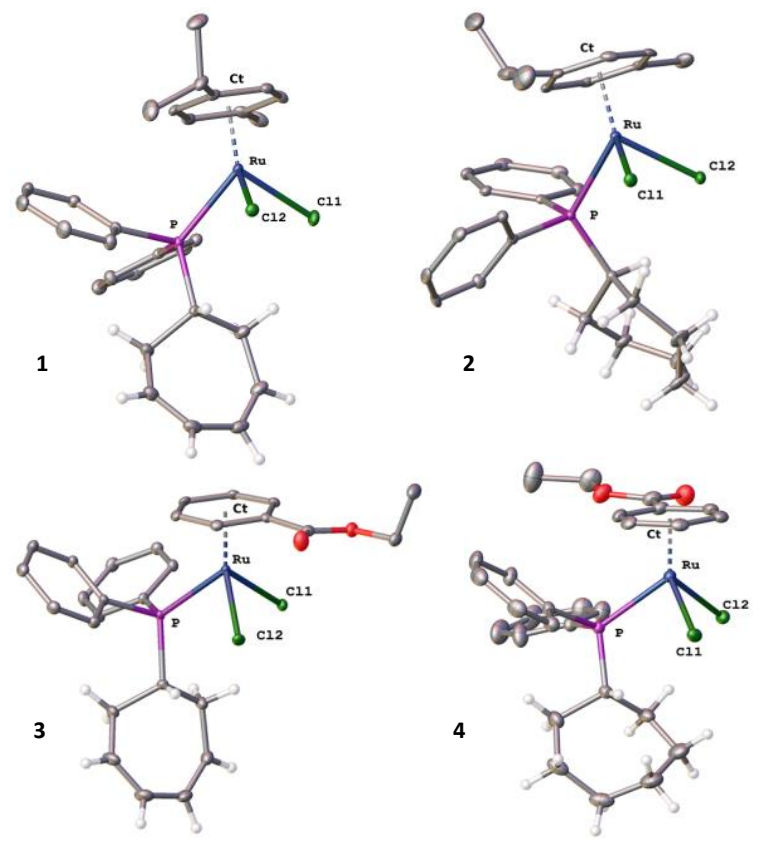

Figure 2: ORTEP views of complexes 1-4 (hydrogen atoms are omitted for clarity). Selected distances $(\AA)$ and angles (deg) in 1-4 order: Ru-Ct 1.6906(10), 1.7114(15), 1.6949(8), 1.6964(14); RuP 2.3885(6), 2.3757(9), 2.3650(5), 2.3787(8); Ru-Cl1 2.4089(6), 2.4091(8), 2.4037(5), 2.3987(7); Ru-Cl2 2.3890(6), 2.4178(8), 2.3959(4), 2.4042(7). Cl1-Ru-Cl2 88.86(2), 86.50(3), 89.391(16), 88.31(3); Cl1-Ru-Ct 123.29(4), 126.59(6), 125.05(3), 124.35(6); Cl1-Ru-P 93.28(2), 90.50(3), 89.727(15); 85.29(3); Cl2-Ru-Ct 126.54(4), 124.82(6), 125.76(3), 124.96(6); Cl2-Ru-P 84.16(2), 87.71(3), 86.553(16), 93.66(3); Ct-Ru-P 128.47(4), 127.89(5), 128.02(3), 128.01(5).

In the four complexes, the arene ruthenium moieties present a three-legged piano stool structure with structural parameters similar to each other and within the range of those observed for related ( $\eta^{6}$-arene $) \mathrm{RuCl}_{2}\left(\mathrm{PR}_{3}\right)$ structures. ${ }^{15}$ The cycloheptadienyl and cycloheptyl rings adopt a half-chair-like conformation and chair-like conformation, respectively, and are oriented in an antiperiplanar conformation with respect to the centroid of the arene ring. In complexes $\mathbf{1}$ and $\mathbf{3}$, the diphenylphosphino group is in pseudo equatorial position on the cycloheptadienyl ring leaving the dienyl moiety away from the Ru centre.

With the aim to check to what extent the dienyl part of the (cycloheptadienyl)phosphine can interact with the $\mathrm{Ru}$ centre once the arene ligand is released, we have first studied the behaviour of $\mathbf{1}$ and $\mathbf{3}$ upon heating. Complex $\mathbf{3}$ with the more labile benzoate ligand was first heated at $50{ }^{\circ} \mathrm{C}$ in $\mathrm{CDCl}_{3}$ in Young NMR tube protected from light. ${ }^{1} \mathrm{H}$ NMR spectrum registered after $16 \mathrm{~h}$ showed only $5 \%$ of free benzoate and no change on ${ }^{31} \mathrm{P}$ NMR spectrum. Prolonged heating for $8 \mathrm{~h}$ at $50{ }^{\circ} \mathrm{C}$ under sunlight led to $60 \%$ of benzoate decoordination and the appearance of a new signal at $100 \mathrm{ppm}$ on ${ }^{31} \mathrm{P}$ NMR spectrum. This difference in kinetics of arene decoordination between darkness and daylight prompt us to study the behaviour of complex $\mathbf{3}$ under photoirradiation. $\mathrm{CDCl}_{3}$ solution of complex 3 was irradiated by $150 \mathrm{~W}$ mercury lamp (Heraeus TQ150W) at room temperature and reaction progress was monitored by NMR. 15 minutes under irradiation were sufficient to see complete decoordination of the benzoate ligand in ${ }^{1} \mathrm{H}$ NMR and the presence of only one peak at $100 \mathrm{ppm}$ on ${ }^{31} \mathrm{P}$ NMR spectrum. Similar evolution was observed with complex 1 but it required $2.5 \mathrm{~h}$ irradiation time (Figure 3).

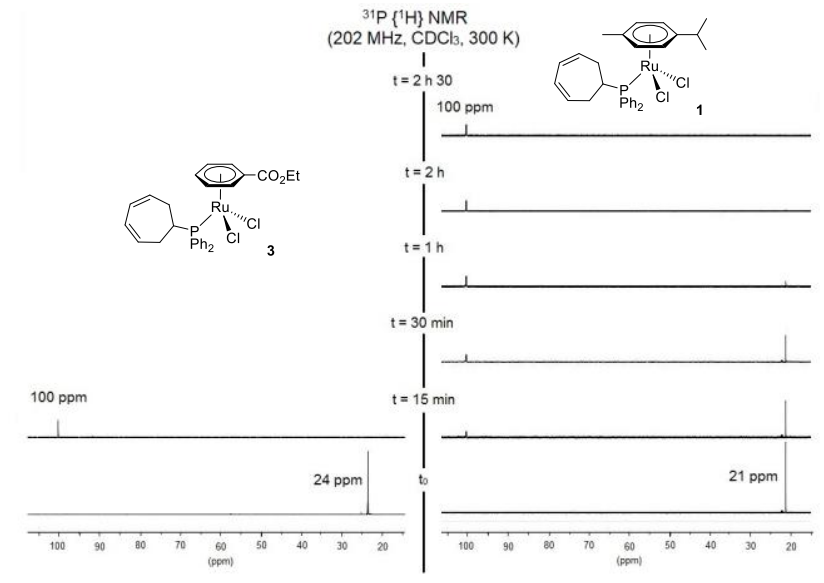

Figure 3: Time course ${ }^{31} \mathrm{P}\left\{{ }^{1} \mathrm{H}\right\}$ NMR spectra $(300 \mathrm{~K})$ of a $\mathrm{CDCl}_{3}$ solution of $\mathbf{1}$ (right) and $\mathbf{3}$ (left) under irradiation (150W Hg Lamp).

The reaction was next carried out from complex 3 at preparative scale in Schlenk tube in $\mathrm{CH}_{2} \mathrm{Cl}_{2}$. One hour under irradiation was necessary to reach completion (Scheme 1). The compound was isolated as brick-red powder after evaporation of $\mathrm{CH}_{2} \mathrm{Cl}_{2}$ and washing with diethyl ether. It was identified as a cationic dinuclear complex 5 based on HRMS, elemental analysis, X-Ray diffraction study and NMR spectroscopies.

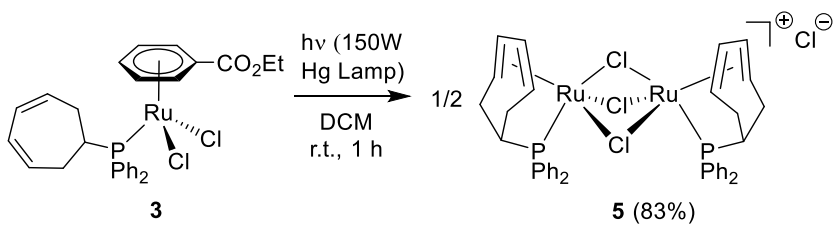

Scheme 1

Expectedly, ${ }^{31} \mathrm{P}$ NMR spectrum of complex 5 displayed a single resonance at $100 \mathrm{ppm} .{ }^{1} \mathrm{H}$ NMR spectrum registered at $253 \mathrm{~K}$ 
showed disappearance of the signals of the benzoate ligand and a split of the signals of the olefinic protons into two multiplets at $\delta=4.89$ and $5.61 \mathrm{ppm}$ of equal intensities, which provides evidence of $\eta^{4}$-coordination of the cycloheptadienyl moiety in solution (similar behaviour was observed in Rh complexes). ${ }^{13}$ Vapour diffusion of pentane into $\mathrm{CDCl}_{3}$ solution of complex (NMR sample) gave suitable crystals for X-Ray diffraction study (Figure 4). The X-Ray analysis confirmed the complete loss of the benzoate ligand and the tridentate coordination of the cycloheptadienyl phosphine. It showed a dinuclear cation in which the two Ru centres are connected by three bridging chlorido ligands. The structure exhibits a two-fold axis passing through the midpoint of $\mathrm{Cl} 2-\mathrm{Cl} 3$ line and $\mathrm{Cl1}$, the two (cycloheptadienyl)phosphine ligands being oriented in a cis-configuration. The two cycloheptadienyl rings adopt a chair-like conformation with the diphenylphosphino group in pseudo axial position, allowing the formation of the $\mathrm{Ru}$-chelates. The bond lengths C3-C4 (1.407(3)), C4-C5 (1.434(3)) and C6-C7 (1.400(3)) range between single and double bound, and clearly indicate the $\pi$-back-bonding character of $\mathrm{Ru}$-diene bonds. The $\mathrm{Ru}-\mathrm{Cl}$ distances are in the expected range with $\mathrm{Ru}-\mathrm{Cl} 1$ bond longer than $\mathrm{Ru}-\mathrm{Cl} 2$ and $\mathrm{Ru}-\mathrm{Cl} 3$ bonds denoting stronger transeffect of the phosphine relative to olefins.

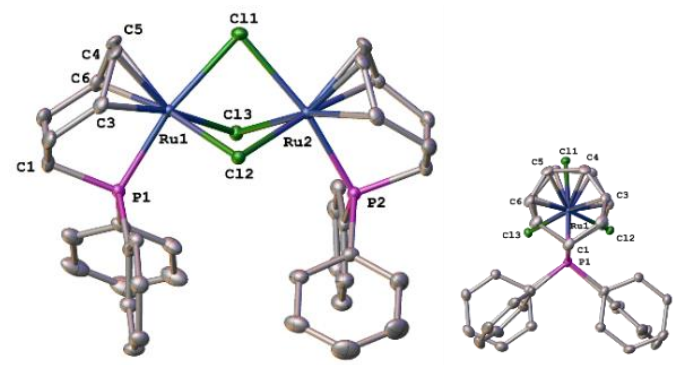

Figure 4: ORTEP views of complex 5 (hydrogen atoms and chloride anion are omitted for clarity). Selected distances $(\AA)$ and angles (deg): Ru1-Cl1 2.5280(5), Ru1-Cl2 2.4355(5), Ru1-Cl3 2.4285(5), Ru1-P1 2.3001(6), Ru1-C3 2.266(2), Ru1-C4 2.145(2), Ru1-C5 2.137(2), Ru1-C6 2.263(2), Ru1-Ct1 2.0910(19), Ru1-Ct2 2.0865(16), P1-C1 1.829(2), C3-C4 1.407(3), C4-C5 1.434(3), C5-C6 1.400(3), Cl1-Ru1-P1 168.802(19), Cl2-Ru1-P1 93.878(19), Cl3-Ru1-P1 92.748(19), Cl1-Ru1-Cl2 79.183(17), Cl1-Ru1-Cl3 77.525(17), Cl2-Ru1-Cl3 80.474(17), C3-Ru1-P1 78.04(6), C3-Ru1-Cl1 111.40(6), C3-Ru1Cl2 97.70(6), C3-Ru1-Cl3 170.51(6), C3-Ru1-C4 37.06(9), C4Ru1-P1 107.66(7), C4-Ru1-Cl1 83.40(7), C4-Ru1-Cl2 116.71(7), C4-Ru1-Cl3 151.45(7).

As mentioned above, photoirradiation of both complexes $\mathbf{1}$ and 3 using Heraeus TQ 150W lamp with a broad emission spectrum (230 to $580 \mathrm{~nm}$ ) led to complex $\mathbf{5}$. With the aim to get more insights into the photochemical behaviors of these complexes, we measured their UV-visible spectra. Complexes $\mathbf{1}$ and 3 show absorption maxima at $369 \mathrm{~nm}$ and $362 \mathrm{~nm}$, respectively, while complex 5 gives band at $411 \mathrm{~nm}$. Consistently, UVvisible monitoring of $\mathrm{CH}_{2} \mathrm{Cl}_{2}$ solution of complexes $\mathbf{1}$ and $\mathbf{3}$ irradiated at $360 \mathrm{~nm}$ showed that both complexes evolved toward 5 within a few minutes (see SI). We next calculated electronic transitions for these systems using a Time-Dependent DFT method (see the Experimental Section). The data nicely reproduce the fact that complexes $\mathbf{1}$ and $\mathbf{3}$ absorb at similar energies while the dimer $\mathbf{5}$ absorbs at lower energy (Table 1). Moreover, while not being quantitative, our estimation of the molar extinction coefficient (computed as $10^{5}$ times the oscillator strength) correspond to a slightly allowed transition: $\varepsilon \sim 1000-2000 \mathrm{~mol}^{-}$ ${ }^{1} \mathrm{~L} \mathrm{~cm}^{-1}$. This is in agreement with the fact that all transitions have only a partial metal to ligand charge transfer character (MLCT). In complexes $\mathbf{1}$ and $\mathbf{3}$, the vacant orbitals involve the $\mathrm{Ru}$-arene and $\mathrm{Ru}$-phosphine bonds while the occupied ones exhibit mainly a metal d block character (Figure 5 and SI). Remarkably, for both complexes, the vacant transition orbital is anti-bonding between the arene and the ruthenium atom, while the occupied one indicates a bonding interaction. This is in line with the fact that irradiating these complexes around $360 \mathrm{~nm}$ will weaken the Ru-Arene bond and eventually lead to dissociation. In complex 5, because of the resonance that takes place between the two metallic centers, the electronic absorption cannot be described by a single pair of natural transition orbitals but rather by a combination of them. This is at the origin of the transition occurring at lower energy. Combining the natural transition orbital localizes the transition on the left ruthenium atom, as shown on figure 5 (bottom) or on the right one (see SI).

Table 1: Theoretical electronic absorption data obtained for the studied systems.

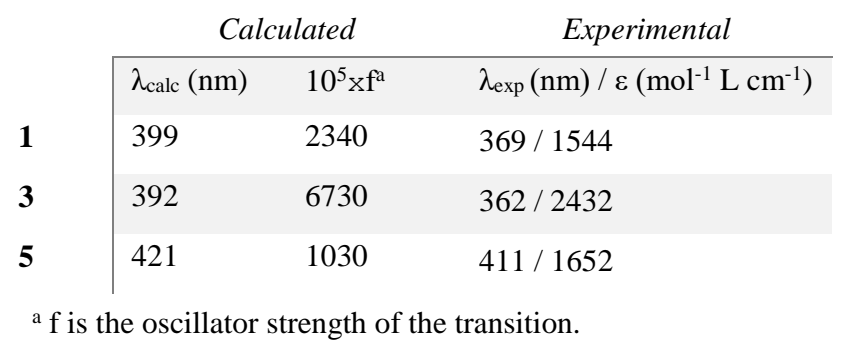

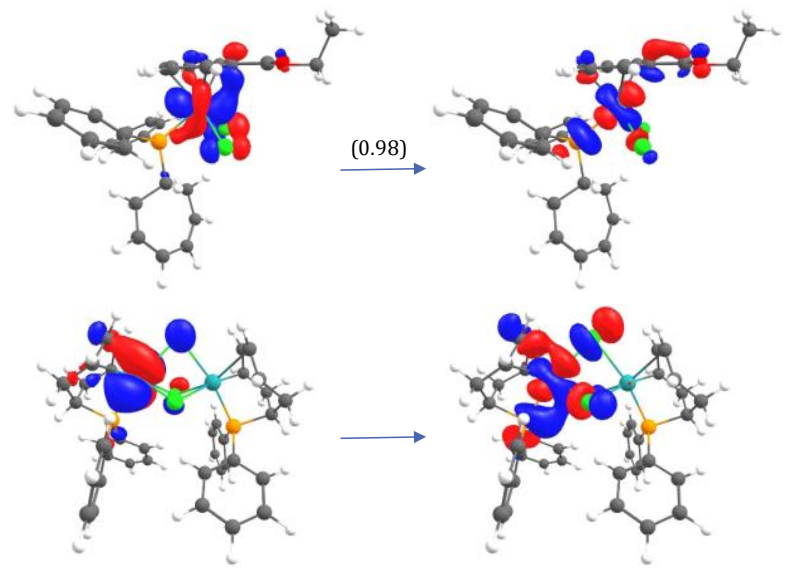

Figure 5: Natural Transition Orbitals of complex 3 (top) and Localized Transition Orbitals of complex 5 (bottom, see also SI). A contour threshold of 0.045 a.u. has been considered. Color code: $\mathrm{C}$ in grey, $\mathrm{P}$ in orange, $\mathrm{Cl}$ in green, $\mathrm{O}$ in red, $\mathrm{Ru}$ in light blue.

Complex 5 shows similarities with the cationic dinuclear $\left[\mathrm{LRu}(\mu-\mathrm{Cl})_{3} \mathrm{RuL}\right]$ complexes reported by Gusev (L= POP pincer ligand), ${ }^{16}$ and those reported by Baker and Brown $(\mathrm{L}=$ bis(NHC) ligands) (Figure 6). ${ }^{17}$ The bimetallic complexes $[(p$ cymene $\left.) \mathrm{Ru}\left(\mu-\mathrm{Cl}_{3}\right) \mathrm{Ru}\left(\mathrm{PR}_{3}\right)\left(\eta^{2}-\mathrm{C}_{2} \mathrm{H}_{4}\right)\right]$ reported by Severin are also particularly relevant to this study ${ }^{9 \mathrm{f}, 9 \mathrm{gj}}$ Beside the similarity of structures, Severin's complexes can be formed by heating a solution of ( $p$-cymene) $\mathrm{RuCl}_{2} \mathrm{PR}_{3}$ with half equivalent of the dimer $\left[\mathrm{Ru}\left(\eta^{6} \text {-arene }\right) \mathrm{Cl}_{2}\right]_{2}$ under ethylene pressure. These compounds revealed among the best precatalysts in ATRA reaction described so far. ${ }^{9 \mathrm{f}, 9 \mathrm{j}}$ A plausible mechanism of formation of these complexes starts with the arene decoordination to generate a coordinatively unsaturated $\left[\mathrm{RuCl}_{2} \mathrm{PR}_{3}\right]$ species which next reacts with the $\mathrm{Ru}$ dimer and ethylene. In case of complex $\mathbf{3}$, we presume that after decoordination of the arene ligand, (cycloheptadienyl)phosphine flips and forms a 16e-chelate $\left[\left\{\left(\eta^{4}-\right.\right.\right.$ 
$\left.\left.\mathrm{C}_{7} \mathrm{H}_{9}\right) \mathrm{PPh}_{2}-\kappa \mathrm{P}\right\} \mathrm{RuCl}_{2}$ ], which subsequently dimerizes to give the dinuclear cation $\mathbf{5}$.

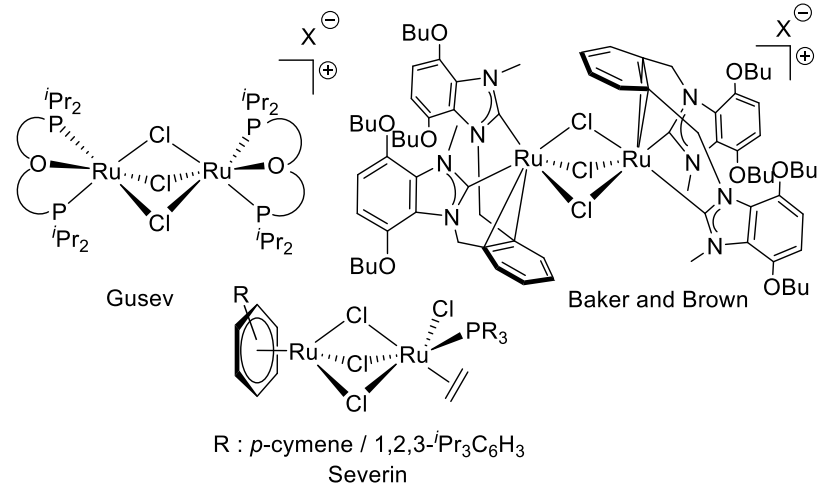

Figure 6: Examples of $\mu-\mathrm{Cl}_{3}$ dinuclear $\mathrm{Ru}$ complexes reported in the literature.

We next investigated the ability of complexes 1-5 to catalyse Kharasch addition of $\mathrm{CCl}_{4}$ to styrene. Considering the ease of arene-Ru bond cleaving under light irradiation, we first studied the impact of light on (arene)Ru-catalysed ATRA reaction. The reactions were conducted in toluene at room temperature using $0.5 \mathrm{~mol} \%$ of ruthenium equiv. ( $0.5 \mathrm{~mol} \%$ of complexes 3,4 or $0.25 \mathrm{~mol} \%$ of complex 5). After $24 \mathrm{~h}$ in the dark, none of the three complexes tested (3-5) showed conversion in the Kharasch adduct. When the reaction mixture was allowed to evolve under natural light for $72 \mathrm{~h}$, (cycloheptadienyl)phosphine complexes $\mathbf{3}$ and $\mathbf{5}$ showed no improvement. Conversely, (cycloheptyl)phosphine complex 4 gave $89 \%$ yield in Kharasch addition. A similar trend was observed using $12 \mathrm{~V} / 55 \mathrm{~W}$ halogen lamp as irradiation source. Among complexes 3-5, only 4 was active and gave $96 \%$ yield of the addition product after $96 \mathrm{~h}$ (Table 2, entries 1-3).

Table 2: Kharasch addition of carbon tetrachloride to styrene under irradiation ${ }^{\mathrm{a}}$

\begin{tabular}{|c|c|c|c|c|c|}
\hline Entry & Cat. & Solvent & Time & $\begin{array}{l}\text { Styrene } \\
\text { conv. }(\%)^{\mathrm{b}}\end{array}$ & $\begin{array}{l}\text { Kharasch } \\
\text { add. }(\%)^{\mathrm{b}}\end{array}$ \\
\hline $1^{\mathrm{c}}$ & 3 & Toluene & $96 \mathrm{~h}$ & 10 & 1 \\
\hline $2^{c}$ & 4 & Toluene & $96 \mathrm{~h}$ & 96 & 96 \\
\hline $3^{c}$ & 5 & Toluene & $96 \mathrm{~h}$ & 13 & 2 \\
\hline $4^{\mathrm{d}}$ & 1 & Toluene & $4 \mathrm{~h}$ & 10 & 2 \\
\hline $5^{\mathrm{d}}$ & 2 & Toluene & $4 \mathrm{~h}$ & 52 & 44 \\
\hline $6^{\mathrm{d}}$ & 3 & Toluene & $4 \mathrm{~h}$ & 2 & 2 \\
\hline $7^{\mathrm{d}}$ & 4 & Toluene & $4 \mathrm{~h}$ & 29 & 29 \\
\hline $8^{\mathrm{d}}$ & 5 & Toluene & $4 \mathrm{~h}$ & 14 & 1 \\
\hline $9^{d}$ & 1 & DCM & $4 \mathrm{~h}$ & 16 & 2 \\
\hline $10^{\mathrm{d}}$ & 2 & DCM & $4 \mathrm{~h}$ & 36 & 21 \\
\hline $11^{\mathrm{d}}$ & 3 & DCM & $4 \mathrm{~h}$ & 5 & 2 \\
\hline $12^{\mathrm{d}}$ & 4 & DCM & $4 \mathrm{~h}$ & 27 & 9 \\
\hline $13^{\mathrm{d}}$ & 5 & DCM & $4 \mathrm{~h}$ & 15 & 1 \\
\hline
\end{tabular}

a $[\text { styrene }]_{0} /\left[\mathrm{CCl}_{4}\right]_{0} /[\text { catalyst }]_{0}=200: 800: 1 .{ }^{\text {b }}$ Determined by GC with dodecane as internal standard. ${ }^{\mathrm{c}} 23^{\circ} \mathrm{C}$, irradiation: halogen $12 \mathrm{~V} / 55 \mathrm{~W} .{ }^{\mathrm{d}} 31^{\circ} \mathrm{C}$, irradiation: Heraeus TQ $150 \mathrm{~W}$.
The reactions were next conducted under irradiation with the $150 \mathrm{~W}$ mercury lamp and stopped after $4 \mathrm{~h}$ for comparative purposes (Table 2, entries 4-8). In these conditions, (cycloheptadienyl)phosphine ruthenium derivatives $\mathbf{1}, \mathbf{3}$ and $\mathbf{5}$ showed very low styrene conversions ( $\max 14 \%$ with 5 ) and only traces of the Kharasch adduct. In the same conditions, (cycloheptyl)phosphine derivatives $\mathbf{2}$ and $\mathbf{4}$ were more active and allowed higher styrene conversions (52\% and $29 \%$, respectively) and higher yields in the addition product (44\% and 29\%, respectively). The use of dichloromethane instead of toluene (Table 2, entries 9-13) did not improve the catalytic activity of $\mathbf{1 , 3}$ and 5 and slightly decreased that of $\mathbf{2}$ and $\mathbf{4}$.

This first set of experiments showed that all three complexes with (cyclopheptadienyl)phosphine 1, $\mathbf{3}$ and $\mathbf{5}$ are unable to promote the Kharasch addition contrary to (cycloheptyl)phosphine $\mathrm{Ru}$ complexes. We assume that complex $\mathbf{5}$ is unreactive because it is coordinatively saturated and irradiation is not sufficient to open coordination site on $\mathrm{Ru}$ for $\mathrm{CCl}_{4}$ activation due to chelate effect. We presume that, under catalytic conditions, both (cycloheptadienyl)complexes $\mathbf{1}$ and $\mathbf{3}$ are converted in the cationic dinuclear complex $\mathbf{5}$ which de facto put at the same level the three complexes. To verify this hypothesis, we registered NMR spectra of toluene and dichloromethane solutions of complex 3 (0.01 mmol), $\mathrm{CCl}_{4}$ (30 eq.) and styrene (20 eq.) after $4 \mathrm{~h}$ under $150 \mathrm{~W}$ mercury lamp irradiation at room temperature (Figure 7). In $\mathrm{CD}_{2} \mathrm{Cl}_{2},{ }^{31} \mathrm{P}$ NMR spectrum displayed the signal of complex 5 at $100 \mathrm{ppm}$. In toluene, we observed the formation of a precipitate which was also further identified as $\mathbf{5}$. In both cases, ${ }^{1} \mathrm{H}$ NMR spectra showed that only traces of Kharasch addition products are formed in these conditions. These results confirm our hypothesis and also demonstrate that $\mathrm{CCl}_{4}$ does not react with the butadiene moiety of the hybrid phosphine. ${ }^{18}$

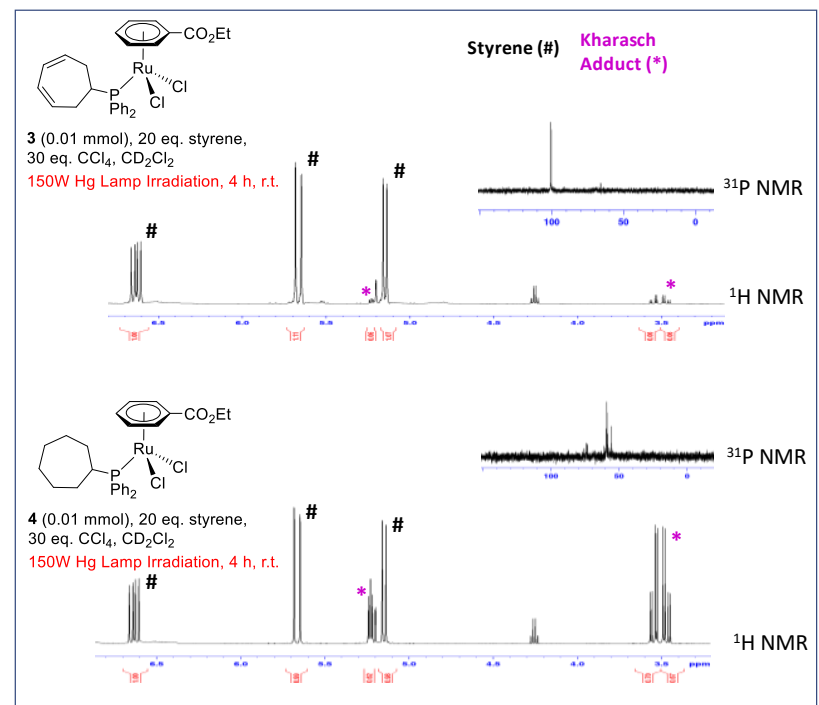

Figure 7: ${ }^{31} \mathrm{P}$ NMR and ${ }^{1} \mathrm{H}$ NMR of complexes 3 (top) and 4 (bottom) in $\mathrm{CD}_{2} \mathrm{Cl}_{2}$ in presence of styrene and $\mathrm{CCl}_{4}$ under irradiation with $150 \mathrm{~W} \mathrm{Hg} \mathrm{Lamp,} 4$ h, r.t.

For comparative purposes, we performed similar experiments with complex 4 under irradiation. In absence of the substrate, ${ }^{31} \mathrm{P}$ NMR spectrum of $\mathrm{CD}_{2} \mathrm{Cl}_{2}$ solution of complex 4 displayed no peak at all and only non-coordinated ethyl benzoate signals were visible by ${ }^{1} \mathrm{H}$ NMR. In presence of ATRA substrates (4: $0.01 \mathrm{mmol}, \mathrm{CCl}_{4}$ : 30 eq. and styrene: 20 eq.), ${ }^{31} \mathrm{P}$ NMR spectrum displayed several peaks ranging from 50 to $80 \mathrm{ppm}$ and ${ }^{1} \mathrm{H}$ NMR analysis showed $65 \%$ Kharasch addition product (Figure 7). UV exposure of toluene solution of $\mathbf{4}$ gave a different result. 
In absence of substrates, the ${ }^{31} \mathrm{P}-\mathrm{NMR}$ spectrum showed complete transformation of $\mathbf{4}(26.2 \mathrm{ppm})$ in [ $\left(\eta^{6}\right.$-toluene $) \mathrm{RuCl}_{2}\{$ (cycloheptyl) $\left.\left.\mathrm{PPh}_{2}\right\}\right] 6$ which presents a signal at $27.8 \mathrm{ppm}$. This product was isolated and the XRD analysis of crystals confirmed the ethyl benzoate replacement by toluene (see SI). In presence of ATRA substrates (4: $0.01 \mathrm{mmol}, \mathrm{CCl}_{4}: 30$ eq. and styrene: 20 eq.), similar transformation of $\mathbf{4}$ in $\mathbf{6}$ was observed, giving also Kharasch addition products in $80 \%$ conversion. This result might appear surprising at first sight because complex 6 is capped by a toluene ligand. Nevertheless, as the irradiation is maintained throughout the reaction, active species can be restored continuously.

We studied the performances in Kharasch addition of complexes 1-5 under heating in the absence of light (Table 3, entries 1-5). The results under irradiation conditions and by heating followed the same trend, but differences emerged between complexes of the same series. After 3 days at $60^{\circ} \mathrm{C}$ in toluene, only (cycloheptyl)phosphine benzoate ruthenium complex 4 allowed total conversion of styrene with very good selectivity toward Kharasch adduct ( $96 \%$ yield, Table 3 entry 4$)$. The other ruthenium complexes $\mathbf{1 - 3}$ and $\mathbf{5}$ gave very low styrene conversion (16-26\%) with a maximum of $13 \%$ yield in Kharasch product with complex 2 . In toluene at $85{ }^{\circ} \mathrm{C}$, both (cycloheptyl)phosphine Ru complexes $\mathbf{2}$ and $\mathbf{4}$ gave Kharasch adduct in good yields $\left(88 \%\right.$ and $98 \%$ yield, respectively). At $85^{\circ} \mathrm{C}$ the (cycloheptadienyl)phosphine ruthenium derivatives $\mathbf{1}$ and $\mathbf{3}$ remained inactive while complex $\mathbf{5}$ showed a significant improvement in performance (Table 3 , entry 10). These differences within cycloheptyl- and cycloheptadienyl Ru complexes series can be explained by the fact that under heating the dissociation of the arene ligand is much slower than under irradiation and becomes a limiting factor.

Table 3: Kharasch addition of carbon tetrachloride to styrene in absence of light at different temperatures ${ }^{\mathrm{a}}$

\begin{tabular}{lllll} 
Entry & Cat. & $\begin{array}{l}\text { Tempera- } \\
\text { ture }\left({ }^{\circ} \mathrm{C}\right)\end{array}$ & $\begin{array}{l}\text { Styrene } \\
\text { conv. }(\%)^{\mathrm{b}}\end{array}$ & $\begin{array}{l}\text { Kharasch add. } \\
(\%)^{\mathrm{b}}\end{array}$ \\
\hline 1 & $\mathbf{1}$ & 60 & 22 & 1 \\
\hline 2 & $\mathbf{2}$ & 60 & 26 & 13 \\
\hline 3 & $\mathbf{3}$ & 60 & 16 & 1 \\
\hline 4 & $\mathbf{4}$ & 60 & 100 & 96 \\
\hline 5 & $\mathbf{5}$ & 60 & 24 & 7 \\
6 & $\mathbf{1}$ & 85 & 35 & 2 \\
\hline 7 & $\mathbf{2}$ & 85 & 100 & 88 \\
\hline 8 & $\mathbf{3}$ & 85 & 22 & 1 \\
\hline 9 & $\mathbf{4}$ & 85 & $100^{\mathrm{c}}$ & $98^{\mathrm{c}}$ \\
\hline 10 & $\mathbf{5}$ & 85 & 48 & 26 \\
\hline
\end{tabular}

${ }^{\mathrm{a}}[\text { styrene }]_{0} /\left[\mathrm{CCl}_{4}\right]_{0} /[\text { catalyst }]_{0}=200: 800: 1$. betermined by GC with dodecane as internal standard after 3 days heating in absence of light. 'Reaction already completed after 1 day.

Aware of this limitation, we next tried to improve the catalytic performances of complexes $\mathbf{2}$ and $\mathbf{4}$ using simultaneous heating and irradiation ( $\mathrm{Hg}$ Lamp). Time course of ATRA between styrene and $\mathrm{CCl}_{4}$ catalyzed by complexes $\mathbf{2}$ and $\mathbf{4}$ under irradiation at $25^{\circ}, 60^{\circ}$ and $85^{\circ} \mathrm{C}$ are presented in Figure 8 . For comparative purpose, conversions obtained at $60^{\circ} \mathrm{C}$ in the absence of light are also reported. Sampling after $1 \mathrm{~h}, 2 \mathrm{~h}$ and $4 \mathrm{~h}$ showed that simultaneous irradiation and heating boost the performances of both complexes. After only $1 \mathrm{~h}$ under irradiation at $85^{\circ} \mathrm{C}$, the yield in Kharasch addition product using complex 4 reached $91 \%$ whereas the same complex gave $9 \%$ yield at $25^{\circ} \mathrm{C}$ and $2 \%$ at $60^{\circ} \mathrm{C}$ in the dark.

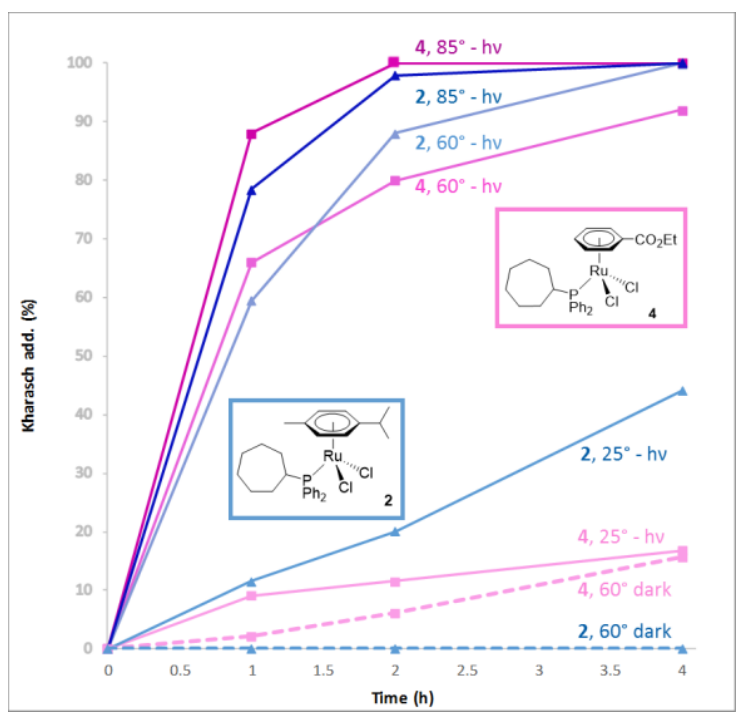

Figure 8: Time course of of Kharasch addition of $\mathrm{CCl}_{4}$ to styrene with ruthenium complexes $\mathbf{2}(\mathbf{\Delta})$ and $\mathbf{4}(\mathbf{\square})$ at different temperatures under $150 \mathrm{~W} \mathrm{Hg}$ Lamp irradiation (continuous lines), or in absence of light (dotted lines) at $60^{\circ} \mathrm{C}$. Conditions: [styrene $]_{0} /\left[\mathrm{CCl}_{4}\right]_{0} /[\text { catalyst }]_{0}=200: 800: 1$, solvent: toluene.

Concerning (cycloheptadienyl)phosphine Ru complexes $\mathbf{1}$ and $\mathbf{3}$, it was clear that light irradiation was not sufficient to generate active species and/or to maintain them alive. On the other hand, we have shown that complex $\mathbf{5}$ can promote ATRA between styrene and $\mathrm{CCl}_{4}$ at $85{ }^{\circ} \mathrm{C}$ but only with moderate activity. NMR experiments conducted with $\mathbf{5}$ showed that it was stable in $\mathrm{C}_{6} \mathrm{D}_{5} \mathrm{Br}$ solution even after prolonged time at $147{ }^{\circ} \mathrm{C}$. We therefore thought that this robustness may allow to improve the TON of the catalyst by authorizing ATRA reactions at elevated temperatures. To test this hypothesis, we carried out addition of $\mathrm{CCl}_{4}$ to styrene in bromobenzene at $147{ }^{\circ} \mathrm{C}$ with only $0.1 \mathrm{~mol} \%$ ruthenium complexes $\mathbf{3 - 5}$ (1:1000 ratio [Ru]/styrene) without any light source (Figure 9).

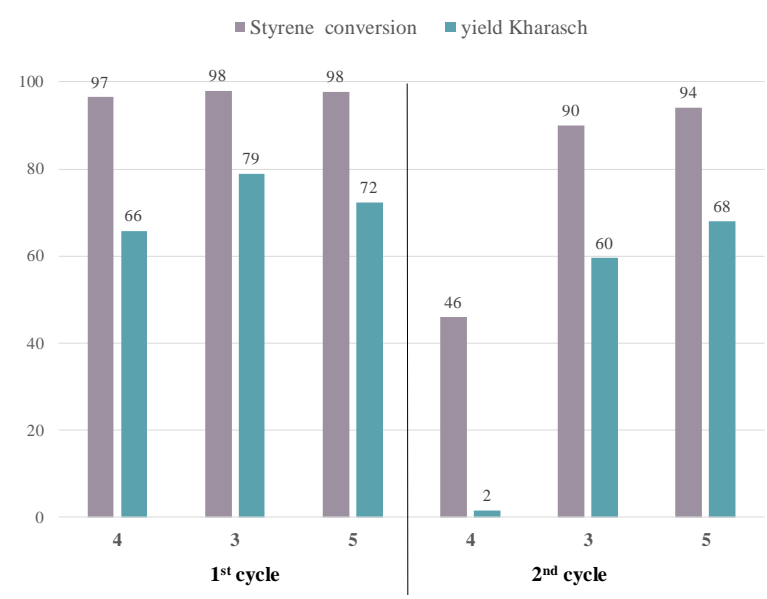

Figure 9: Kharasch addition with complexes 3-5 in bromobenzene at $147^{\circ} \mathrm{C}($ dark $) ; 1^{\text {st }}$ cycle: $[\text { styrene }]_{0} /\left[\mathrm{CCl}_{4}\right]_{0} /[\text { catalyst }]_{0}$ $=1000: 4000: 1(18 \mathrm{~h}) ; 2^{\text {nd }}$ cycle by adding $[$ styrene $] /\left[\mathrm{CCl}_{4}\right] /[$ catalyst $]=1000: 4000: 0(22 \mathrm{~h})$ 
After $18 \mathrm{~h}$ all three complexes gave almost total conversions of styrene and good yields in Kharasch adduct. To test further the stability of the catalysts, a second cycle was run by adding the same amount of substrates to the reaction mixture. After another $22 \mathrm{~h}$ at $147^{\circ} \mathrm{C}$, complex 4 showed reduced activity giving only small amount of Kharasch adduct. In contrary, complexes $\mathbf{3}$ and $\mathbf{5}$ were still active, the latter showing almost the same performances than during the first cycle. Lower catalyst loading of $\mathbf{5}$ has been also tested (Table 4). The reaction with $\mathbf{5}$ using a styrene/[Ru] ratio of 5000 gave $74 \%$ yield in Kharasch addition product $(\mathrm{TON}=3700)$. We next investigated ATRA reaction of alternative substrates like 1-octene and tetradecene with $\mathrm{CCl}_{4}$ using complex 5 at an olefin/[Ru] ratio of 10000 . This gave Kharasch adduct in $95 \%$ and $98 \%$ yields, respectively, after 48 $\mathrm{h}$ at $147^{\circ} \mathrm{C}(\mathrm{TON}=9500$ and 9700 , respectively $)$. With analogous substrates, monometallic $\left[\mathrm{RuCl}_{2}\right.$ (arene $\left.)\left(\mathrm{PR}_{3}\right)\right]$ complexes described by Demonceau gave TON ranging from 150 to $280 .^{2 b}$, ${ }^{11}$ The bimetallic complexes $\left[(p\right.$-cymene $) \mathrm{Ru}\left(\mu-\mathrm{Cl}_{3}\right) \mathrm{Ru}\left(\mathrm{PR}_{3}\right)\left(\eta^{2}\right.$ $\left.\mathrm{C}_{2} \mathrm{H}_{4}\right)$ ] reported by Severin reached TON of 1500 but needs $\mathrm{Mg}$ as a cocatalyst for regenerating $\mathrm{Ru}^{\mathrm{II}}$ from the $\mathrm{Ru}^{\mathrm{III}}$ active species. ${ }^{9 \mathrm{j}}$ The best complex $\left[\mathrm{Cp} * \mathrm{RuCl}_{2}\left(\mathrm{PPh}_{3}\right)\right]$ reported so far reach TON of 13.200 for styrene and 44.500 for 1 -hexene but requires the use of AIBN as cocatalyst. ${ }^{9 \mathrm{~g}}$ These last values are clearly superior to those obtained in this study but with complex $\mathbf{5}$, no cocatalyst is needed.

Table 4: Kharasch addition of carbon tetrachloride to olefins at low catalyst loading of $\mathbf{5}^{\mathrm{a}}$

\begin{tabular}{llllll}
\hline $\begin{array}{l}\text { En } \\
\text { try }\end{array}$ & Olefin & $\begin{array}{l}\text { S/[Ru] } \\
\text { ratio }\end{array}$ & $\begin{array}{l}\text { Styrene } \\
\text { conv. }(\%)^{\mathrm{d}}\end{array}$ & $\begin{array}{l}\text { Kharasch } \\
\text { add. }(\%)^{\mathrm{d}}\end{array}$ & TON \\
\hline $1^{\mathrm{b}}$ & styrene & 5000 & 96 & 74 & 3700 \\
$2^{\mathrm{c}}$ & $\begin{array}{l}\text { 1-octene } \\
10000\end{array}$ & 96 & 95 & 9500 \\
$3^{\mathrm{c}}$ & $\begin{array}{l}\text { 1-tetrade- } \\
\text { cene }\end{array}$ & 10000 & 98 & 97 & 9700 \\
\hline
\end{tabular}

${ }^{\mathrm{a}}$ conditions : reaction in bromobenzene $(4 \mathrm{~mL})$ at $147^{\circ} \mathrm{C}$ for $48 \mathrm{~h}$ in the absence of light, ${ }^{\mathrm{b}}$ styrene $(10 \mathrm{mmol}), \mathrm{CCl}_{4}(40 \mathrm{mmol}), 5$

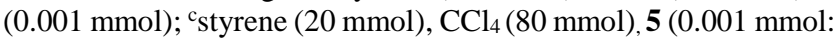
$0.002 \mathrm{mmol}[\mathrm{Ru}])$; ${ }^{\mathrm{d}}$ Determined by GC with dodecane as internal standard.

\section{CONCLUSION}

In summary, we have described the synthesis of a series of (arene) $\mathrm{RuCl}_{2} \mathrm{PR}_{3}$ complexes with (cycloheptadienyl)- and (cycloheptyl)diphenylphosphine. Upon irradiation or heating in toluene, all these complexes lose arene ligand but then behave differently depending on the nature of the phosphine ligand. (Cycloheptadienyl)phosphine complexes $\mathbf{1}$ and $\mathbf{3}$ give a cationic dinuclear Ru complex $\mathbf{5}$ bridged by three chlorido ligands and flanked by two tridendate (cycloheptadienyl)phosphine, whose structure has been confirmed by X-Ray diffraction study. Complexes 2 and 4 undergo arene exchange with toluene. ATRA catalytic trials conducted in parallel with these complexes using $\mathrm{CCl}_{4}$ and styrene as standard substrates, highlighted the deep impact of the dienyl moiety on the results. In smooth conditions (UV irradiation or moderate heating), only (cycloheptyl)phosphine derivatives give Karasch adduct in satisfactory yields. Their performance were further considerably improved by combining irradiation and heating conditions. At higher temperature, the cationic dinuclear complex 5 revealed active and robust, giving turnover numbers close to $10^{4}$ when octene (or tetradecene) and $\mathrm{CCl}_{4}$ were used as substrates.

\section{EXPERIMENTAL SECTION}

General considerations. All reactions, except when indicated, were carried out under an atmosphere of purified argon using conventional Schlenk techniques. DCM, diethyl ether, THF, toluene, and pentane were dried using a MBRAUN SPS 800. [( $\eta^{6}$ - $p$-cymene $\left.) \mathrm{RuCl}_{2}\right]_{2},{ }^{19}\left[\left(\eta^{6}\right.\right.$ ethyl benzoate) $\left.\mathrm{RuCl}_{2}\right]_{2}{ }^{20}$ and (3,5-cycloheptadienyl)diphenylphosphine ${ }^{14}$ have been synthesized according to literature procedure. Other reagents were commercially available and used as received from suppliers unless otherwise specified. Analyses were performed at the "Plateforme d'Analyses Chimiques de Synthèse Moléculaire de l'Universite de Bourgogne". The identity and purity $(\geq 95 \%)$ of the compounds were unambiguously established using elemental analyses, multinuclear NMR spectroscopy, X-ray diffraction analysis, high-resolution mass spectrometry, and Infrared. Elemental analyses were obtained on a Flash EA 1112 CHNS-O Thermo Electron Flash instrument. NMR spectra $\left({ }^{1} \mathrm{H},{ }^{13} \mathrm{C},{ }^{31} \mathrm{P}\right)$ were recorded on Bruker 300 Avance III or Bruker 500 Avance III spectrometers. All acquisitions, except when indicated, were performed at $300 \mathrm{~K}$. Chemical shifts are quoted in parts per million ( $\delta$ ) relative to TMS (for ${ }^{1} \mathrm{H}$ and ${ }^{13} \mathrm{C}$ ) or $85 \% \mathrm{H}_{3} \mathrm{PO}_{4}$ (for ${ }^{31} \mathrm{P}$ ). For ${ }^{1} \mathrm{H}$ and ${ }^{13} \mathrm{C}$ spectra, values were determined by using solvent residual signals (e.g. $\mathrm{CHCl}_{3}$ in $\mathrm{CDCl}_{3}$ ) as internal standards. For ${ }^{31} \mathrm{P}, 85 \% \mathrm{H}_{3} \mathrm{PO}_{4}$ was used as an external standard. The coupling constants $(J)$ are reported in Hertz $(\mathrm{Hz})$. Multiplicity abbreviations: $\mathrm{s}=$ singlet, $\mathrm{bs}=$ broad singlet, $\mathrm{d}=$ doublet, $\mathrm{t}=$ triplet, $\mathrm{q}=$ quartet, $\mathrm{dd}=$ doublet of doublets. Assignment of ${ }^{1} \mathrm{H}$ and ${ }^{13} \mathrm{C}$ signals (when possible) was done through the use of DEPT and 2D experiences (COSY, HSQC). High resolution mass spectra were recorded on a Thermo LTQ Orbitrap XL ESI-MS (ElectroSpray Ionization Mass Spectrometry). Infrared spectra were recorded on a Bruker Vertex 70v spectrophotometer fitted with a Globar MIR source, a Ge/KBr (MIR) or silicon (FIR) beam splitter, a DLaTGS detector and a diamond ATR module. UV-Visible absorption spectra were recorded on a JASCO V630BIO spectrometer. The irradiation experiments were performed by using a JASCO FP8500 spectrofluorometer instrument.

X-Ray experimental procedure: suitable crystals for X-ray analysis were selected and mounted on a mylar loop with oil on a 'Bruker APEX-II CCD' diffractometer. Crystals were kept at $115 \mathrm{~K}$ during data collections. Using Olex $2^{21}$, the structures were solved with the ShelXT ${ }^{22}$ structure solution program using Direct Methods and refined with the $\mathrm{XL}^{23}$ refinement package using Least Squares minimization against $|\mathrm{F}|$. In 2, the cycloheptyl group was found disordered and two conformations were refined with occupation factors converged to $0.55 / 0.45$. For $\mathbf{5}$, one of the four chloroform solvate molecules present in the asymmetric unit was found disordered over two positions and both components were refined with occupation factors converged to $0.54 / 0.46$

Computational Details: All DFT and TD-DFT calculations were carried out with the Gaussian09 code,${ }^{24}$ tightening self-consistent field convergence thresholds $\left(10^{-10}\right.$ a.u. $)$. Geometry optimizations without symmetry constraints and the corresponding frequency calculations were conducted with a LANL2TZ(f) ${ }^{25}$ basis set and a pseudo-potential for the Ruthenium atom, and a $631+\mathrm{G}(\mathrm{d})$ basis set for all other atoms. ${ }^{26,27,28}$ The hybrid functional PBE0 ${ }^{29}$ was selected given its good performance in previous DFT studies involving ruthenium-containing systems. ${ }^{30}$ Vertical excitations were computed with TD-DFT using a larger basis set, i.e. the 6-311++G(d,p) for $\mathrm{H}, \mathrm{C}, \mathrm{N}, \mathrm{O}$, and $\mathrm{Cl}$ and the LANL2TZ(f) basis sets and pseudo-potential for the metal. TD-DFT calculations were performed with the PBE0 functional. For each complex, 24 states were considered. The solvent effects of dichloromethane were included according to the Polarizable Continuum Model. ${ }^{31,32}$ This procedure allows to reproduce the UV absorption spectrum of our complexes, as shown in the Supporting Information. All orbital isosurfaces have been plotted with the Chemcraft $\operatorname{code}^{33}$ considering a contour threshold of 0.045 a.u. The orbital transitions of selected excited states were characterized using the natural transition orbital (NTO) method. ${ }^{34}$ The LANL2TZ (f) basis set and pseudopotentials were taken from the EMSL Basis Set Exchange Web site. ${ }^{35}$

Cycloheptyldiphenylphosphine. Diphenylphosphine (1 eq., $2.10 \mathrm{~g}$, $11.3 \mathrm{mmol})$ was diluted in diethyl ether $(10 \mathrm{~mL}) . N$-butyllithium (1 eq., 
$11.3 \mathrm{mmol}, 2.5 \mathrm{M}$ in hexanes, $4.52 \mathrm{~mL}$ ) was slowly added, and the resulting mixture was stirred $1 \mathrm{~h}$; a yellow color was observed. Bromocycloheptane ( 1 eq., $11.3 \mathrm{mmol}, 2.00 \mathrm{~g}$ ) was slowly added, and the reaction mixture was stirred $16 \mathrm{~h}$. The volatiles were evaporated. The residue was extracted with pentane $(3 \times 20 \mathrm{~mL})$. The filtrate was concentrated to give $\mathbf{I}-5$ as a white solid $(2.99 \mathrm{~g}, 94 \%)$.Elemental Analysis: calcd for $\mathrm{C}_{19} \mathrm{H}_{23} \mathrm{P}: \mathrm{C}, 80.82 ; \mathrm{H}, 8.21$. Found: $\mathrm{C}, 80.96 ; \mathrm{H}, 8.35$. HR-MS (ESI-pos): calcd for $\left[\mathrm{C}_{19} \mathrm{H}_{24} \mathrm{P}\right]^{+}[\mathrm{M}+\mathrm{H}]^{+}$: 283.16101. Found: 283.16061 (-1.4 ppm). ${ }^{1} \mathrm{H}$ NMR $\left(500 \mathrm{MHz}, \mathrm{CD}_{2} \mathrm{Cl}_{2}\right): \delta(\mathrm{ppm})=7.53$ $7.47(\mathrm{~m}, 4 \mathrm{H}, o-\mathrm{Ph}), 7.35-7.27(\mathrm{~m}, 4 \mathrm{H}+2 \mathrm{H}, m-\mathrm{Ph}, p-\mathrm{Ph}), 2.46-2.38$ (m, 1H, PCH), 1.76-1.66 (m, 4H, cycloheptyl), 1.65-1.59 (m, 2H, cycloheptyl), 1.58-1.45 (m, 4H, cycloheptyl), 1.44-1.33 (m, 2H, cycloheptyl). ${ }^{13} \mathrm{C}\left\{{ }^{1} \mathrm{H}\right\}$ NMR $\left(125.8 \mathrm{MHz}, \mathrm{CD}_{2} \mathrm{Cl}_{2}\right): \delta(\mathrm{ppm})=138.8\left(\mathrm{~d},{ }^{1} J_{\mathrm{CP}}\right.$ $=15.5 \mathrm{~Hz}, i-\mathrm{Ph}), 134.0\left(\mathrm{~d},{ }^{2} J_{\mathrm{CP}}=19.1 \mathrm{~Hz}, o-\mathrm{Ph}\right), 129.0(\mathrm{~s}, p-\mathrm{Ph}), 128.7$ $\left(\mathrm{d},{ }^{3} J_{\mathrm{CP}}=6.9 \mathrm{~Hz}, m-\mathrm{Ph}\right), 35.8\left(\mathrm{~d},{ }^{1} J_{\mathrm{CP}}=9.6 \mathrm{~Hz}, \mathrm{PCH}\right), 31.4\left(\mathrm{~d},{ }^{2} J_{\mathrm{CP}}=\right.$ $\left.18.4 \mathrm{~Hz}, \mathrm{PCHCH}_{2}\right), 29.0\left(\mathrm{~s}, \mathrm{PCHCH}_{2} \mathrm{CH}_{2} \mathrm{CH}_{2}\right), 28.6\left(\mathrm{~d},{ }^{3} J_{\mathrm{CP}}=12.4 \mathrm{~Hz}\right.$, $\left.\mathrm{PCHCH}_{2} \mathrm{CH}_{2}\right) .{ }^{31} \mathrm{P}\left\{{ }^{1} \mathrm{H}\right\}$ NMR $\left(202.4 \mathrm{MHz}, \mathrm{CD}_{2} \mathrm{Cl}_{2}\right): \delta(\mathrm{ppm})=-2.8$ (s).

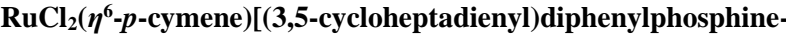
$\boldsymbol{\kappa P}]$ (1). $\left[\mathrm{RuCl}_{2}\left(\eta^{6}-p \text {-cymene) }\right]_{2}\right.$ (1 eq., $\left.524 \mathrm{mg}, 0.856 \mathrm{mmol}\right)$ and cycloheptadienyldiphenylphosphine ( 2.2 eq., $524 \mathrm{mg}, 1.88 \mathrm{mmol}$ ) in toluene $(15 \mathrm{~mL})$ were stirred at room temperature for $16 \mathrm{~h}$ in the dark. The solvent was evaporated. The residue was triturated and washed with pentane, and dried to give 1 as an orange solid (940 mg, 94\%). Elemental Analysis: calcd for $\mathrm{C}_{29} \mathrm{H}_{33} \mathrm{Cl}_{2} \mathrm{PRu}$ : C, 59.59; H, 5.69. Found: $\mathrm{C}$, 59.59; H, 5.81. HR-MS (ESI-pos): calcd for $\left[\mathrm{C}_{30} \mathrm{H}_{36} \mathrm{OPRu}\right]^{+}[\mathrm{M}-2 \mathrm{Cl}$ $+\mathrm{OMe}^{+}:$545.15418. Found: $545.15414(-0.1 \mathrm{ppm}) .{ }^{1} \mathrm{H}$ NMR $(500$ $\left.\mathrm{MHz}, \mathrm{CD}_{2} \mathrm{Cl}_{2}\right): \delta(\mathrm{ppm})=7.94-7.87(\mathrm{~m}, 4 \mathrm{H}, o-\mathrm{Ph}), 7.56-7.43(\mathrm{~m}, 4 \mathrm{H}$ $+2 \mathrm{H}, m-\mathrm{Ph}, p-\mathrm{Ph}), 5.80-5.68(\mathrm{~m}, 4 \mathrm{H}$, diene $), 5.03-4.96(\mathrm{~m}, 2 \mathrm{H}, \mathrm{MeC}-$ $\left.{ }_{\mathrm{q}} \mathrm{C} \underline{\mathrm{H}}\right), 4.89\left(\mathrm{~d},{ }^{3} J_{\mathrm{HH}}=6.1 \mathrm{~Hz}, 2 \mathrm{H},{ }^{i}{ }{ } \mathrm{C}_{\mathrm{q}} \mathrm{C} \underline{\mathrm{H}}\right), 3.42-3.32(\mathrm{~m}, 1 \mathrm{H}, \mathrm{PC} \underline{\mathrm{H}})$, $3.03-2.95\left(\mathrm{~m}, 2 \mathrm{H}, \mathrm{PCHCH}_{\mathrm{a}} \mathrm{H}_{\mathrm{b}}\right), 2.57$ (hept, $\left.{ }^{3} J_{\mathrm{HH}}=6.9 \mathrm{~Hz}, 1 \mathrm{H}, \mathrm{CH}^{i} \mathrm{Pr}\right)$, $1.81(\mathrm{~s}, 3 \mathrm{H}, \mathrm{Me}), 1.72-1.63\left(\mathrm{~m}, 2 \mathrm{H}, \mathrm{PCHCH}_{\mathrm{a}} \mathrm{H}_{\mathrm{b}}\right), 1.02\left(\mathrm{~d},{ }^{3} J_{\mathrm{HH}}=7.0\right.$ $\left.\mathrm{Hz}, 6 \mathrm{H}, \mathrm{CH}_{3}{ }^{i} \mathrm{Pr}\right) .{ }^{13} \mathrm{C}\left\{{ }^{1} \mathrm{H}\right\}$ NMR $\left(126 \mathrm{MHz}, \mathrm{CD}_{2} \mathrm{Cl}_{2}\right): \delta(\mathrm{ppm})=134.1$ $\left(\mathrm{d},{ }^{2} J_{\mathrm{CP}}=8.3 \mathrm{~Hz}, o-\mathrm{Ph}\right), 133.1\left(\mathrm{~d},{ }^{1} J_{\mathrm{CP}}=39.1 \mathrm{~Hz}, i\right.$-Ph, overlapping with $\left.\mathrm{PCHCH}_{2} \mathrm{CH}=\mathrm{CH}\right), 133.0\left(\mathrm{~d},{ }^{3} J_{\mathrm{CP}}=14.5 \mathrm{~Hz}, \mathrm{PCHCH}_{2} \mathrm{CH}=\mathrm{CH}\right.$, overlapping with $i-\mathrm{Ph}), 130.9\left(\mathrm{~d},{ }^{4} J_{\mathrm{CP}}=2.6 \mathrm{~Hz}, p-\mathrm{Ph}\right), 128.5\left(\mathrm{~d},{ }^{3} J_{\mathrm{CP}}=\right.$ $9.1 \mathrm{~Hz}, m-\mathrm{Ph}), 125.7\left(\mathrm{~s}, \mathrm{PCHCH}_{2} \mathrm{CH}=\mathrm{CH}\right), 109.7\left(\mathrm{~s},{ }^{i} \operatorname{Pr}_{q}\right), 95.3(\mathrm{~s}$, $\left.\mathrm{MeC}_{\mathrm{q}}\right), 91.2\left(\mathrm{~d},{ }^{2} J_{\mathrm{CP}}=4.0 \mathrm{~Hz}, \mathrm{MeC}_{\mathrm{q}} \mathrm{CH}\right), 85.7\left(\mathrm{~d},{ }^{2} J_{\mathrm{CP}}=5.6 \mathrm{~Hz}\right.$, $\left.{ }^{i} \mathrm{PrC}_{\mathrm{q}} \mathrm{CH}\right), 35.1\left(\mathrm{~d},{ }^{1} J_{\mathrm{CP}}=19.1 \mathrm{~Hz}, \mathrm{PCH}\right), 33.7\left(\mathrm{~s}, \mathrm{PCHCH}_{2}\right), 30.6(\mathrm{~s}$, $\mathrm{CH}{ }^{i} \mathrm{Pr}$ ), 22.1 (s, $\left.\mathrm{CH}_{3}{ }^{i} \mathrm{Pr}\right), 17.8$ (s, Me). ${ }^{31} \mathrm{P}\left\{{ }^{1} \mathrm{H}\right\} \mathrm{NMR}(202 \mathrm{MHz}$, $\left.\mathrm{CD}_{2} \mathrm{Cl}_{2}\right): \delta(\mathrm{ppm})=21.3(\mathrm{~s})$. Selected IR Bands (ATR): wavenumber $\left(\mathrm{cm}^{-1}\right)=290\left(v_{\mathrm{Ru}-\mathrm{Cl}}\right)$

$\mathbf{R u C l}_{\mathbf{2}}\left(\boldsymbol{\eta}^{\mathbf{6}}\right.$ - $\boldsymbol{p}$-cymene)(cycloheptyldiphenylphosphine- $\left.\boldsymbol{\kappa} \mathbf{P}\right)$

(2).

$\left[\mathrm{RuCl}_{2}\left(\eta^{6}-p \text {-cymene }\right)\right]_{2}(1$ eq., $520 \mathrm{mg}, 0.849 \mathrm{mmol})$ and cycloheptyldiphenylphosphine (2.2 eq., $528 \mathrm{mg}, 1.87 \mathrm{mmol})$ in toluene $(15 \mathrm{~mL})$ were stirred at room temperature for $16 \mathrm{~h}$ in the dark. The solvent was evaporated. The residue was triturated and washed with pentane, and dried to give $\mathbf{2}$ as an orange powder (902 mg, 90\%). Elemental Analysis: calcd for $\mathrm{C}_{29} \mathrm{H}_{37} \mathrm{Cl}_{2} \mathrm{PRu}$ : C, 59.18; H, 6.34. Found: C, 59.02; H, 6.32. HR-MS (ESI-pos): calcd for $\left[\mathrm{C}_{29} \mathrm{H}_{37} \mathrm{ClPRu}\right]^{+}[\mathrm{M}-\mathrm{Cl}]^{+}: 553.13594$ Found: $553.13416(-3.2 \mathrm{ppm}) .{ }^{1} \mathrm{H}$ NMR $\left(500 \mathrm{MHz}, \mathrm{CD}_{2} \mathrm{Cl}_{2}\right): \delta(\mathrm{ppm})$ = 7.95-7.87 (m, 4H, o- $\mathrm{Ph}), 7.52-7.43(\mathrm{~m}, 4 \mathrm{H}+2 \mathrm{H}, m-\mathrm{Ph}, p-\mathrm{Ph}), 4.97-$ $4.94\left(\mathrm{~m}, 2 \mathrm{H}, \mathrm{MeC}_{\mathrm{q}} \mathrm{CH}\right), 4.86\left(\mathrm{~d},{ }^{3} J_{\mathrm{HH}}=6.1 \mathrm{~Hz}, 2 \mathrm{H},{ }^{i} \operatorname{PrC}_{\mathrm{q}} \mathrm{CH}\right), 3.18$ $3.07(\mathrm{~m}, 1 \mathrm{H}, \mathrm{PC} \underline{\mathrm{H}}), 2.58$ (hept, ${ }^{3} J_{\mathrm{HH}}=7.0 \mathrm{~Hz}, 1 \mathrm{H}, \mathrm{CH}{ }^{i} \mathrm{Pr}$ ), $2.30-2.19$ $\left(\mathrm{m}, 2 \mathrm{H}, \mathrm{PCHCH}{ }_{\mathrm{a}} \mathrm{H}_{\mathrm{b}}\right), 1.80$ (s, 3H, Me), 1.53-1.45 (m, 4H, cycloheptyl), 1.44-1.37 (m, 2H, cycloheptyl), 1.37-1.27 (m, 2H, cycloheptyl), 1.04 $\left(\mathrm{d},{ }^{3} J_{\mathrm{HH}}=7.0 \mathrm{~Hz}, 6 \mathrm{H}, \mathrm{CH}_{3}{ }^{i} \mathrm{Pr}\right), 0.80-0.94\left(\mathrm{~m}, 2 \mathrm{H}, \mathrm{PCHCH}_{\mathrm{a}} \mathrm{H}_{\mathrm{b}}\right)$. ${ }^{13} \mathrm{C}\left\{{ }^{1} \mathrm{H}\right\}$ NMR $\left(126 \mathrm{MHz}, \mathrm{CD}_{2} \mathrm{Cl}_{2}\right): \delta(\mathrm{ppm})=134.2\left(\mathrm{~d},{ }^{2} J_{\mathrm{CP}}=8.1 \mathrm{~Hz}\right.$, $o-\mathrm{Ph}), 133.9\left(\mathrm{~d},{ }^{1} J_{\mathrm{CP}}=38.4 \mathrm{~Hz}, i-\mathrm{Ph}\right), 130.6\left(\mathrm{~d},{ }^{4} J_{\mathrm{CP}}=2.6 \mathrm{~Hz}, p-\mathrm{Ph}\right)$, $128.3\left(\mathrm{~d},{ }^{3} J_{\mathrm{CP}}=9.1 \mathrm{~Hz}, m-\mathrm{Ph}\right), 109.4\left(\mathrm{~s}, \mathrm{C}_{\mathrm{g}}{ }^{i} \mathrm{Pr}\right), 95.1\left(\mathrm{~s}, \mathrm{C}_{\mathrm{g}} \mathrm{Me}\right), 91.0(\mathrm{~d}$, $\left.{ }^{2} J_{\mathrm{CP}}=3.9 \mathrm{~Hz}, \mathrm{MeC}_{\mathrm{q}} \mathrm{CH}\right), 85.7\left(\mathrm{~d},{ }^{2} J_{\mathrm{CP}}=5.7 \mathrm{~Hz},{ }^{i} \operatorname{PrC}_{\mathrm{q}} \mathrm{CH}\right) 35.8\left(\mathrm{~d},{ }^{1} J_{\mathrm{CP}}\right.$ $=20.6 \mathrm{~Hz} ; \mathrm{PCH}), 30.6\left(\mathrm{~s}, \mathrm{CH}{ }^{i} \mathrm{Pr}\right), 30.2\left(\mathrm{~d},{ }^{3} J_{\mathrm{CP}}=1.8 \mathrm{~Hz}\right.$, $\left.\mathrm{PCHCH}_{2} \mathrm{CH}_{2}\right), 28.6\left(\mathrm{~d},{ }^{2} J_{\mathrm{CP}}=13.4 \mathrm{~Hz}, \mathrm{PCHCH}_{2}\right), 28.0(\mathrm{~s}$, $\mathrm{PCHCH}_{2} \mathrm{CH}_{2} \mathrm{CH}_{2}$ ), 22.1 (s, $\left.\mathrm{CH}_{3}{ }^{i} \mathrm{Pr}\right), 17.8$ (s, Me). ${ }^{31} \mathbf{P}\left\{{ }^{1} \mathbf{H}\right\}$ NMR $(202$ $\left.\mathrm{MHz}, \mathrm{CD}_{2} \mathrm{Cl}_{2}\right): \delta(\mathrm{ppm})=23.7$ (s). Selected IR Bands (ATR): wavenumber $\left(\mathrm{cm}^{-1}\right)=293\left(v_{\mathrm{Ru}-\mathrm{Cl}}\right)$.

$\mathrm{RuCl}_{2}\left(\eta^{6}\right.$-BzOEt $)[(3,5$-cycloheptadienyl)diphenylphosphine- $\kappa \mathrm{P}]$ (3). $\left[\mathrm{RuCl}_{2}\left(\eta^{6}-\mathrm{BzOEt}\right)\right]_{2}(1$ eq., $536 \mathrm{mg}, 0.833 \mathrm{mmol})$ and cycloheptadyenyldiphenylphosphine ( $2.2 \mathrm{eq} ., 510 \mathrm{mg}, 1.83 \mathrm{mmol})$ in toluene $(15 \mathrm{~mL})$ were stirred at room temperature for $16 \mathrm{~h}$ in the dark. The solvent was evaporated. The residue was triturated and washed with pentane, and dried to give 3 as an orange solid (930 mg, 90\%). Elemental Analysis: calcd for $\mathrm{C}_{28} \mathrm{H}_{29} \mathrm{Cl}_{2} \mathrm{O}_{2} \mathrm{PRu}$ : C, $56.01 ; \mathrm{H}, 4.87$. Found: C, 56.04; H, 5.13. HR-MS (ESI-pos): calcd for $\left[\mathrm{C}_{28} \mathrm{H}_{29} \mathrm{Cl}_{2} \mathrm{O}_{2} \mathrm{PRuNa}\right]^{+}$ $[\mathrm{M}+\mathrm{Na}]^{+}: 623.02179$. Found: $623.02230(0.8 \mathrm{ppm}) .{ }^{1} \mathrm{H}$ NMR $(500$ $\left.\mathrm{MHz}, \mathrm{CD}_{3} \mathrm{CN}\right): \delta(\mathrm{ppm})=7.93-7.81(\mathrm{~m}, 4 \mathrm{H}, o-\mathrm{Ph}), 7.59-7.53(\mathrm{~m}, 2 \mathrm{H}$, $p$-Ph), 7.48-7.55 (m, 4H, $m$-Ph), $6.23\left(\mathrm{~d},{ }^{3} J_{\mathrm{HH}}=6.5 \mathrm{~Hz}, 2 \mathrm{H}, o\right.$-BzOEt), $5.80-5.68(\mathrm{~m}, 4 \mathrm{H}$, diene $), 5.44-5.36(\mathrm{~m}, 1 \mathrm{H}, p-\mathrm{BzOEt}), 4.85\left(\mathrm{t},{ }^{3} \mathrm{~J}_{\mathrm{HH}}=\right.$ $5.6 \mathrm{~Hz}, 2 \mathrm{H}, m-\mathrm{BzOEt}), 4.32\left(\mathrm{q},{ }^{3} \mathrm{JHH}_{\mathrm{HH}}=7.1 \mathrm{~Hz}, 2 \mathrm{H}, \mathrm{OCH}_{2} \mathrm{CH}_{3}\right), 3.49$ $3.38(\mathrm{~m}, 1 \mathrm{H}, \mathrm{PCH}), 2.97-2.86\left(\mathrm{~m}, 2 \mathrm{H}, \mathrm{PCHCH}_{\mathrm{a}} \mathrm{H}_{\mathrm{b}}\right), 1.79-1.68(\mathrm{~m}, 2 \mathrm{H}$, $\left.\mathrm{PCHCH}_{\mathrm{a}} \underline{\mathrm{H}}_{\mathrm{b}}\right), 1.33\left(\mathrm{t},{ }^{3} \mathrm{~J}_{\mathrm{HH}}=7.1 \mathrm{~Hz}, 3 \mathrm{H}, \mathrm{OCH}_{2} \mathrm{C}_{3}\right) .{ }^{13} \mathrm{C}\left\{{ }^{1} \mathrm{H}\right\} \mathrm{NMR}$ $\left(125.8 \mathrm{MHz}, \mathrm{CD}_{3} \mathrm{CN}\right): \delta(\mathrm{ppm})=165.0(\mathrm{~s}, \mathrm{C}=\mathrm{O}), 134.6\left(\mathrm{~d},{ }^{2} J_{\mathrm{CP}}=8.3\right.$ $\mathrm{Hz}, o-\mathrm{Ph}), 133.5\left(\mathrm{~d},{ }^{3} J_{\mathrm{CP}}=14.7 \mathrm{~Hz}, \mathrm{PCHCH}_{2} \underline{\mathrm{CH}}=\mathrm{CH}\right), 133.0\left(\mathrm{~d},{ }^{1} J_{\mathrm{CP}}\right.$ $=42.5 \mathrm{~Hz}, i-\mathrm{Ph}), 131.9\left(\mathrm{~d},{ }^{4} J_{\mathrm{CP}}=2.6 \mathrm{~Hz}, p-\mathrm{Ph}\right), 129.3\left(\mathrm{~d},{ }^{3} J_{\mathrm{CP}}=9.6 \mathrm{~Hz}\right.$, $m$-Ph), $126.3\left(\mathrm{~s}, \mathrm{PCHCH}{ }_{2} \mathrm{CH}=\underline{\mathrm{CH}}\right), 96.6\left(\mathrm{~d},{ }^{2} J_{\mathrm{CP}}=3.3 \mathrm{~Hz}, o-\mathrm{BzOEt}\right)$, $91.2\left(\mathrm{~s}, p\right.$-BzOEt), $87.3\left(\mathrm{~d},{ }^{2} J_{\mathrm{CP}}=7.8 \mathrm{~Hz}, p\right.$-BzOEt), $85.4\left(\mathrm{~d},{ }^{2} J_{\mathrm{CP}}=2.7\right.$ $\mathrm{Hz}, m$-BzOEt), 63.1 (s, $\left.\mathrm{OCH}_{2} \mathrm{CH}_{3}\right), 36.3\left(\mathrm{~d},{ }^{1} J_{\mathrm{CP}}=20.1 \mathrm{~Hz}, \mathrm{PCH}\right), 34.3$ $\left(\mathrm{d},{ }^{2} J_{\mathrm{CP}}=1.4 \mathrm{~Hz}, \mathrm{PCHCH}{ }_{2}\right), 14.9\left(\mathrm{~s}, \mathrm{OCH}_{2} \mathrm{CH}_{3}\right) .{ }^{31} \mathrm{P}\left\{{ }^{1} \mathrm{H}\right\} \mathrm{NMR}(202.4$ $\left.\mathrm{MHz}, \mathrm{CD}_{3} \mathrm{CN}\right): \delta(\mathrm{ppm})=25.4(\mathrm{~s})$. Selected IR Bands (ATR): wave-

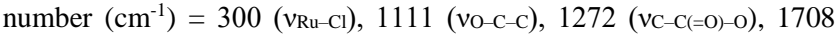
$\left(v_{\mathrm{C}=0}\right)$.

$\mathrm{RuCl}_{2}\left(\eta^{6}\right.$-BzOEt)(cycloheptyldiphenylphosphine- $\left.\boldsymbol{\kappa} \mathbf{P}\right) \quad$ (4). $\quad\left[\eta^{6}-\right.$ (ethyl benzoate) $\left.\mathrm{RuCl}_{2}\right]_{2}$ (1 eq., $533 \mathrm{mg}, 0.827 \mathrm{mmol}$ ) and cycloheptyldiphenylphosphine (2.2 eq., $514 \mathrm{mg}, 1.82 \mathrm{mmol})$ in toluene $(15 \mathrm{~mL})$ were stirred at room temperature for $16 \mathrm{~h}$ in the dark. The solvent was evaporated. The residue was triturated and washed with pentane, and dried to give 4 as an orange solid (950 mg, 95\%). Elemental Analysis: calcd for $\mathrm{C}_{28} \mathrm{H}_{33} \mathrm{Cl}_{2} \mathrm{O}_{2} \mathrm{PRu}$ : C, 55.63; H, 5.50. Found: $\mathrm{C}, 56.13 ; \mathrm{H}, 5.52$. HR-MS (ESI-pos): calcd for $\left[\mathrm{C}_{28} \mathrm{H}_{33} \mathrm{Cl}_{2} \mathrm{O}_{2} \mathrm{PRuNa}\right]^{+}\left[\mathrm{M}+\mathrm{Na}^{+}\right.$: 627.05309. Found: 627.05280. (-0.5 ppm). ${ }^{1} \mathrm{H}$ NMR $(500 \mathrm{MHz}$, $\left.\mathrm{CD}_{2} \mathrm{Cl}_{2}\right): \delta(\mathrm{ppm})=7.91-7.84(\mathrm{~m}, 4 \mathrm{H}, o-\mathrm{Ph}), 7.54-7.46(\mathrm{~m}, 4 \mathrm{H}+2 \mathrm{H}$, $m$-Ph, $p$-Ph), $6.28\left(\mathrm{~d},{ }^{3} J_{\mathrm{HH}}=6.6 \mathrm{~Hz}, 2 \mathrm{H}, o-\mathrm{BzOEt}\right), 5.30-5.31(\mathrm{~m}, 1 \mathrm{H}$, $p$-BzOEt, overlapping with $\mathrm{CD}_{2} \mathrm{Cl}_{2}$ residual signal), $4.71\left(\mathrm{t},{ }^{3} J_{\mathrm{HH}}=5.8\right.$ $\mathrm{Hz}, 2 \mathrm{H}, m$-BzOEt), $4.36\left(\mathrm{q},{ }^{3} J_{\mathrm{HH}}=7.1 \mathrm{~Hz}, 2 \mathrm{H}, \mathrm{OCH}_{2} \mathrm{CH}_{3}\right), 3.26-3.17$ $(\mathrm{m}, 1 \mathrm{H}, \mathrm{PCH}), 2.22-2.13\left(\mathrm{~m}, 2 \mathrm{H}, \mathrm{PCHCH}_{\mathrm{a}} \mathrm{H}_{\mathrm{b}}\right), 1.56-1.45(\mathrm{~m}, 4 \mathrm{H}, \mathrm{cy}-$ cloheptyl overlapping with $\mathrm{H}_{2} \mathrm{O}$ signal), $1.45-1.30$ (m, 4H, cycloheptyl overlapping with $\mathrm{OCH}_{2} \mathrm{CH}_{3}$ signal), $1.38\left(\mathrm{t},{ }^{3} J_{\mathrm{HH}}=7.1 \mathrm{~Hz}, 3 \mathrm{H}\right.$, $\mathrm{OCH}_{2} \mathrm{CH}_{3}$ overlapping with cycloheptyl signal), $1.06-0.95(\mathrm{~m}, 2 \mathrm{H}$, $\left.\mathrm{PCHCH}_{\mathrm{a}} \mathrm{H}_{\mathrm{b}}\right) .{ }^{13} \mathrm{C}\left\{{ }^{1} \mathrm{H}\right\} \mathrm{NMR}\left(126 \mathrm{MHz}, \mathrm{CD}_{2} \mathrm{Cl}_{2}\right): \delta(\mathrm{ppm})=164.4(\mathrm{~s}$, $\mathrm{C}=\mathrm{O}), 134.0\left(\mathrm{~d},{ }^{2} J_{\mathrm{CP}}=8.0 \mathrm{~Hz}, o-\mathrm{Ph}\right), 133.1\left(\mathrm{~d},{ }^{1} J_{\mathrm{CP}}=41.5 \mathrm{~Hz}, i-\mathrm{Ph}\right)$, $131.0\left(\mathrm{~d},{ }^{4} J_{\mathrm{CP}}=2.4 \mathrm{~Hz}, p-\mathrm{Ph}\right), 128.5\left(\mathrm{~d},{ }^{3} J_{\mathrm{CP}}=9.4 \mathrm{~Hz}, m-\mathrm{Ph}\right), 96.3(\mathrm{~d}$, ${ }^{2} J_{\mathrm{CP}}=3.1 \mathrm{~Hz}, o$-BzOEt), $91.0\left(\mathrm{~s}, p\right.$-BzOEt), $86.1\left(\mathrm{~d},{ }^{2} J_{\mathrm{CP}}=7.4 \mathrm{~Hz}, i-\right.$ $\mathrm{BzOEt}), 84.3\left(\mathrm{~d},{ }^{2} J_{\mathrm{CP}}=2.8 \mathrm{~Hz}, m-\mathrm{BzOEt}\right), 62.8\left(\mathrm{~s}, \mathrm{O}^{\mathrm{C}} \mathrm{H}_{2} \mathrm{CH}_{3}\right), 36.1(\mathrm{~d}$, $\left.{ }^{1} J_{\mathrm{CP}}=21.9 \mathrm{~Hz}\right), 30.4\left(\mathrm{~d},{ }^{2} J_{\mathrm{CP}}=2.2 \mathrm{~Hz}, \mathrm{PCHCH}_{2}\right), 28.6\left(\mathrm{~d},{ }^{3} J_{\mathrm{CP}}=13.9\right.$ $\left.\mathrm{Hz}, \mathrm{PCHCH}_{2} \mathrm{CH}_{2}\right), 27.9$ (s, $\left.\mathrm{PCHCH}_{2} \mathrm{CH}_{2} \underline{\mathrm{CH}}_{2}\right), 14.7\left(\mathrm{~s}, \mathrm{OCH}_{2} \mathrm{CH}_{3}\right)$. ${ }^{31} \mathrm{P}\left\{{ }^{1} \mathrm{H}\right\} \operatorname{NMR}\left(202 \mathrm{MHz}, \mathrm{CD}_{2} \mathrm{Cl}_{2}\right): \delta(\mathrm{ppm})=27.7$ (s). Selected IR Bands (ATR): wavenumber $\left(\mathrm{cm}^{-1}\right)=294\left(v_{\mathrm{Ru}-\mathrm{Cl}}\right), 1098\left(v_{\mathrm{O}-\mathrm{C}-\mathrm{C}}\right), 1263$

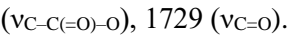

$\left[\mathrm{Ru}_{2}(\mu-\mathrm{Cl})_{3}\left(\left(\eta^{4}-3,5\right.\right.\right.$-cycloheptadienyl $)$ diphenylphosphine-

$\left.\boldsymbol{\kappa} \mathbf{P})_{2}\right][\mathbf{C l}]$ (5). Complex $\mathbf{3}(240 \mathrm{mg}, 0.400 \mathrm{mmol})$ was dissolved in DCM $(8 \mathrm{~mL})$, and exposed to light (mercury lamp Heraeus TQ150W) for $1 \mathrm{~h}$ under stirring. Solvent was evaporated. The residue was washed with diethyl ether and dried to give $\mathbf{5}$ as a brick red powder (150 mg, 83\%). Elemental Analysis: calcd for $\mathrm{C}_{38} \mathrm{H}_{38} \mathrm{Cl}_{4} \mathrm{P}_{2} \mathrm{Ru}_{2}$ : C, 50.68; H, 4.25. Found: C, 50.36; H, 4.33. HR-MS (ESI-pos) calcd for $\left[\mathrm{C}_{38} \mathrm{H}_{38} \mathrm{Cl}_{3} \mathrm{P}_{2} \mathrm{Ru}_{2}\right]^{+}[\mathrm{M}-\mathrm{Cl}]^{+}:$864.96014. Found: 864.95562. (-3.4 ppm). ${ }^{1} \mathrm{H}$ NMR $\left(500 \mathrm{MHz}, \mathrm{CDCl}_{3}, 253 \mathrm{~K}\right): \delta(\mathrm{ppm})=7.59-7.49(\mathrm{~m}$, $8 \mathrm{H}+4 \mathrm{H}, o / m-\mathrm{Ph}, p-\mathrm{Ph}), 7.35-7.29(\mathrm{~m}, 8 \mathrm{H}, o / m-\mathrm{Ph}), 5.61-5.55(\mathrm{~m}, 4 \mathrm{H}$, $\left.\mathrm{CH}_{2} \mathrm{CH}=\mathrm{C} \underline{\mathrm{H}}\right), 4.88-4.81\left(\mathrm{~m}, 4 \mathrm{H}, \mathrm{CH}_{2} \mathrm{CH}=\mathrm{CH}\right), 2.99-2.94(\mathrm{~m}, 2 \mathrm{H}$, PCH), $1.97-1.88\left(\mathrm{~m}, 4 \mathrm{H}, \mathrm{PCHCH}_{\mathrm{a}} \mathrm{H}_{\mathrm{b}}\right), 0.90\left(\mathrm{dd},{ }^{3} J_{\mathrm{CP}}=46.3 \mathrm{~Hz},{ }^{2} J_{\mathrm{HH}}\right.$ $\left.=14.3 \mathrm{~Hz}, 4 \mathrm{H}, \mathrm{PCHCH}_{\mathrm{a}} \mathrm{H}_{\mathrm{b}}\right) \cdot{ }^{13} \mathbf{C}\left\{{ }^{1} \mathbf{H}\right\} \mathbf{N M R}\left(126 \mathrm{MHz}, \mathrm{CDCl}_{3}, 253 \mathrm{~K}\right)$ : $\delta(\mathrm{ppm})=134.0\left(\mathrm{~d}, J_{\mathrm{CP}}=8.5 \mathrm{~Hz}, o / m \mathrm{Ph}\right), 132.1\left(\mathrm{~d},{ }^{4} J_{\mathrm{CP}}=2.4 \mathrm{~Hz}, p-\right.$ $\mathrm{Ph}), 128.9\left(\mathrm{~d}, J_{\mathrm{CP}}=10.3 \mathrm{~Hz}, o / m \mathrm{Ph}\right), 128.0\left(\mathrm{~d},{ }^{1} J_{\mathrm{CP}}=48.3 \mathrm{~Hz}, i-\mathrm{Ph}\right)$, 87.6 (s, $\mathrm{CH}_{2} \mathrm{CH}=\underline{\mathrm{CH}}$ ), 77.6 (s, overlapping with $\mathrm{CDCl}_{3}, \mathrm{CH}_{2} \mathrm{CH}=\mathrm{CH}$ ), $51.8\left(\mathrm{~d},{ }^{1} J_{\mathrm{CP}}=36.0 \mathrm{~Hz}, \mathrm{PC} H\right), 27.6\left(\mathrm{~d},{ }^{2} J_{\mathrm{CP}}=6.8 \mathrm{~Hz}, \mathrm{PCHCH}_{2}\right)$. ${ }^{31} \mathrm{P}\left\{{ }^{1} \mathrm{H}\right\}$ NMR $\left(202 \mathrm{MHz}, \mathrm{CD}_{2} \mathrm{Cl}_{2}, 253 \mathrm{~K}\right): \delta(\mathrm{ppm})=100.0$ (bs).

$\mathrm{RuCl}_{2}\left(\eta^{6}\right.$-toluene)(cycloheptyldiphenylphosphine- $\left.\kappa \mathrm{P}\right)$ (6). In a NMR tube $20 \mathrm{mg}(0.033 \mathrm{mmol})$ of complex 4 were dissolved in toluene and irradiated at room temperature with $150 \mathrm{~W}$ mercury lamp to give after $3 \mathrm{~h}$ complete conversion in complex $\mathbf{6}$ which was further isolated as red crystals. ${ }^{1} \mathrm{H} \mathrm{NMR}\left(500 \mathrm{MHz}, \mathrm{CDCl}_{3}\right): \delta(\mathrm{ppm})$ =7.94-7.86 (m, 4H, Ph), 7.51-7.43 (m, 6H, Ph), 5.08-5.03 (m, 2H, CH Tol), $4.95\left(\mathrm{bd},{ }^{3} J_{\mathrm{HH}}=5.8 \mathrm{~Hz}, 2 \mathrm{H}, \mathrm{CH} \mathrm{Tol}\right), 4.40\left(\mathrm{bt},{ }^{3} \mathrm{~J}_{\mathrm{HH}}=5.2 \mathrm{~Hz}, 1 \mathrm{H}\right.$, 
CH Tol), 3.34-3.26 (m, 1H, PCH), 2.26-2.15 (m, 2H, cycloheptyl), 2.13 (s, 3H, $\left.\mathrm{CH}_{3}-\mathrm{Tol}\right), 1.57-1.37$ (m, 6H, cycloheptyl), 1.36-1.26 (m, $2 \mathrm{H}$, cycloheptyl), 1.04-0.94 (m, 2H, cycloheptyl). ${ }^{13} \mathrm{C}\left\{{ }^{1} \mathrm{H}\right\}$ NMR $(126$ $\left.\mathrm{MHz}, \mathrm{CDCl}_{3}\right): \delta(\mathrm{ppm})=133.8\left(\mathrm{~d},{ }^{1} J_{\mathrm{CP}}=39.6 \mathrm{~Hz}, \mathrm{C}_{\mathrm{q}} i-\mathrm{Ph}\right), 133.5(\mathrm{~d}$, $\left.J_{\mathrm{CP}}=8.0 \mathrm{~Hz}, \mathrm{CH} \mathrm{Ph}\right), 130.33\left(\mathrm{~d}, J_{\mathrm{CP}}=1.9 \mathrm{~Hz}, \mathrm{CH} \mathrm{Ph}\right), 128.2\left(\mathrm{~d}, J_{\mathrm{CP}}=\right.$ $9.9 \mathrm{~Hz}, \mathrm{CH} \mathrm{Ph}), 107.3$ (d, $\left.J_{\mathrm{CP}}=4.6 \mathrm{~Hz}, \mathrm{C}_{\mathrm{q}} \mathrm{Tol}\right), 89.1$ (s, CH Tol), 88.3 $\left(\mathrm{d}, J_{\mathrm{CP}}=5.4 \mathrm{~Hz}, \mathrm{CH} \mathrm{Tol}\right), 80.8(\mathrm{~s}, \mathrm{CH}$ Tol$), 34.9\left(\mathrm{~d},{ }^{1} J_{\mathrm{CP}}=20.8 \mathrm{~Hz}\right.$ PCH), $29.9\left(\mathrm{~d}, J_{\mathrm{CP}}=2.0 \mathrm{~Hz}, \mathrm{CH}_{2}\right.$-cycloheptyl), $28.3\left(\mathrm{~d}, J_{\mathrm{CP}}=13.4 \mathrm{~Hz}\right.$, $\mathrm{CH}_{2}$-cycloheptyl), 27.5 (s, $\mathrm{CH}_{2}$-cycloheptyl), 18.6 (s, $\mathrm{CH}_{3}$-Tol). ${ }^{31} \mathrm{P}\left\{{ }^{1} \mathrm{H}\right\}$ NMR $\left(202 \mathrm{MHz}, \mathrm{CDCl}_{3}\right): \delta(\mathrm{ppm})=28.4(\mathrm{~s})$.

Kharasch addition : In a typical experiment styrene ( $2 \mathrm{mmol}), \mathrm{CCl}_{4}$ $(8 \mathrm{mmol})$, dodecane (internal standard, $0.44 \mathrm{mmol}), \mathrm{Ru}$ complex $(0.01$ mmol of $\mathbf{1 - 4}$ or $0.005 \mathrm{mmol} \mathrm{5} ; 0.5 \mathrm{~mol} \%$ to styrene) and $2 \mathrm{~mL}$ of the appropriate solvent were introduced in a Schlenk tube in the glove box and then irradiated with $150 \mathrm{~W}$ mercury lamp (Heraeus TQ 150W) or heated to the desired temperature under light protection. The styrene conversion and the yield of the Kharasch adduct were determined by GC after calibration with respect to the internal standard. All solvents and reagents were dried and kept under argon prior to use. The sampling of the reaction mixture was made in the glove box under argon.

GC method : $100^{\circ} \mathrm{C}, 10^{\circ} / \mathrm{min}, 220^{\circ} \mathrm{C}(10 \mathrm{~min})$, column flow: 1 $\mathrm{mL} \cdot \mathrm{mn}^{-1}$, split ratio:100, column : QUADREX 60329B, length $30.0 \mathrm{~m}$, Inner diameter $0.25 \mathrm{~mm}$, Film Thickness $0.25 \mu \mathrm{m}$.

\section{ASSOCIATED CONTENT}

\section{Supporting Information}

The Supporting Information is available free of charge on the ACS Publications website.

${ }^{1} \mathrm{H},{ }^{13} \mathrm{C},{ }^{31} \mathrm{P}$ NMR spectra of complexes 1-6, UV visible spectra of complexes 1-5, evolution of UV-Visible spectra of compounds 1 and 3 under irradiation at $360 \mathrm{~nm}$, tables of crystal data for complexes 1-6 and calculated transition orbitals of complexes 1, 3 and 5.

\section{Accession Codes}

CCDC 1578509-1578514 contain the supplementary crystallographic data for this paper. These data can be obtained free of charge via www.ccdc.cam.ac.uk/data_request/cif, or by emailing data request@ccdc.cam.ac.uk, or by contacting The Cambridge Crystallographic Data Centre, 12 Union Road, Cambridge CB2 1EZ, UK; fax: +44 1223336033 .

\section{AUTHOR INFORMATION}

\section{Corresponding Author}

* E-mail: pierre.le-gendre @u-bourgogne.fr; Tel: +33 (0)3 8039 60 82; raluca.malacea@u-bourgogne.fr; Tel: +33 (0)3 803990 38.

\section{ACKNOWLEDGMENT}

This work is supported by the CNRS, Universite de Bourgogne, Conseil Régional de Bourgogne through the plan d'actions régional pour l'innovation (PARI) and the fonds européen de développement regional (FEDER) programs.

\section{REFERENCES}

1) For reviews see: (a) Rigby, J. H.; Kondratenko, M. A.: Arene Complexes as Catalysts. In Transition Metal Arene $\pi$-Complexes in Organic Synthesis and Catalysis; Kündig, E. P., Ed.; Springer Berlin Heidelberg: Berlin, Heidelberg, 2004; pp 181-204. (b) Therrien, B. Coord. Chem. Rev. 2009, 253, 493-519. (c) Delaude, L.; Demonceau, A. Dalton Trans. 2012, 41, 9257-9268. (d) Kumar, P.; Gupta, R. K.; Pandey, D. S. Chem. Soc. Rev. 2014, 43, 707-733. (e) Crochet, P.; Cadierno, V. Dalton Trans. 2014, 43, 12447-12462.
2) (a) Richel, A.; Demonceau, A.; Noels, A. F. Tetrahedron Lett. 2006, 47, 2077-2081. (b) Borguet, Y.; Richel, A.; Delfosse, S.; Leclerc, A.; Delaude, L.; Demonceau, A. Tetrahedron Lett. 2007, 48, 6334-6338.

3) (a) Kharasch, M. S.; Engelmann, H.; Mayo, F. R. J. Org. Chem. 1937, 2, 288-302.

4) (a) Gossage, R. A.; van de Kuil, L. A.; van Koten, G. Acc. Chem. Res. 1998, 31, 423-431. (b) Iqbal, J.; Bhatia, B.; Nayyar, N. K. Chem. Rev. 1994, 94, 519-564.

5) Bennett, M. A.; Robertson, G. B.; Smith, A. K. J. Organomet. Chem. 1972, 43, C41-C43.

6) (a) Fürstner, A.; Ackermann, L. Chem. Commun. 1999, 95-96. (b) Delaude, L.; Demonceau, A.; Noels, A. F. Chem. Commun. 2001 986-987. (c) Fürstner, A.; Liebl, M.; Lehmann, C. W.; Picquet, M.; Kunz, R.; Bruneau, C.; Touchard, D.; Dixneuf, P. H. Chem. Eur. J. 2000, 6, 1847-1857.

7) Simal, F.; Demonceau, A.; Noels, A. F. Angew. Chem., Int. Ed. 1999, 38, 538-540.

8) For reviews, see: (a) Delaude, L.; Demonceau, A.; Noels, A. F. Top. Organomet. Chem. 2004, 11, 155-171. (b) Severin, K. Curr. Org. Chem. 2006, 10, 217. (c) Severin, K. Chimia 2012, 66, 386388

9) Selected references on Ru-catalysed ATRA: (a) Matsumoto, H.; Nakano, T.; Nagai, Y. Tetrahedron Lett. 1973, 14, 5147-5150. (b) Simal, F.; Wlodarczak, L.; Demonceau, A.; Noels, A. F. Eur. J. Org. Chem. 2001, 2689-2695. (c) Opstal, T.; Verpoort, F. Tetrahedron Lett. 2002, 43, 9259-9263. (d) Tutusaus, O.; Viñas, C.; Núñez, R.; Teixidor, F.; Demonceau, A.; Delfosse, S.; Noels, A. F.; Mata, I.; Molins, E. J. Am. Chem. Soc. 2003, 125, 11830-11831. (e) Quebatte, L.; Haas, M.; Solari, E.; Scopelliti, R.; Nguyen, Q. T.; Severin, K. Angew. Chem., Int. Ed. 2005, 44, 1084-1088. (f) Quebatte, L.; Solari, E.; Scopelliti, R.; Severin, K. Organometallics 2005, 24, 1404-1406. (g) Quebatte, L.; Thommes, K.; Severin, K. J. Am. Chem. Soc. 2006, 128, 7440-7441. (h) Thommes, K.; Içli, B.; Scopelliti, R.; Severin, K. Chem. Eur. J. 2007, 13, 6899-6907. (i) Lundgren, R. J.; Rankin, M. A.; McDonald, R.; Stradiotto, M. Organometallics 2008, 27, 254 258. (j) Wolf, J.; Thommes, K.; Briel, O.; Scopelliti, R.; Severin, K. Organometallics 2008, 27, 4464-4474. (k) Solari, E.; Gauthier, S.; Scopelliti, R.; Severin, K. Organometallics 2009, 28, 4519-4526. (1) Nair, R. P.; Kim, T. H.; Frost, B. J. Organometallics 2009, 28, 46814688 (m) Lee, J.; Grandner, J. M.; Engle, K. M.; Houk, K. N.; Grubbs, R. H. J. Am. Chem. Soc. 2016, 138, 7171-7177.

10) Simal, F.; Jan, D.; Demonceau, A.; Noels, A. F.: Atom Transfer Radical Polymerization Mediated by Ruthenium(II)-Arene Complexes. In Controlled/Living Radical Polymerization; ACS Symposium Series 768; American Chemical Society, 2000; Vol. 768; pp 223-233.

11) Baraut, J.; Massard, A.; Chotard, F.; Bodio, E.; Picquet, M.; Richard, P.; Borguet, Y.; Nicks, F.; Demonceau, A.; Le Gendre, P. Eur. J. Inorg. Chem. 2015, 2671-2682.

12) For other examples of using hydrid phosphine-diene ligands in catalysis, see: (a) Kaddouri, H.; Vicente,V.; Ouali, A.; Ouazzani, F.; Taillefer, M. Angew. Chem., Int. Ed. 2009, 48, 333-336. (b) Nishimura, T.; Maeda, Y.; Hayashi, T. Org. Lett. 2011, 13, 3674-3677. (c) Geng, W.; Zhang, W.-X.; Hao, W.; Xi, Z. J. Am. Chem. Soc. 2012, 134, 20230-20233. (d) Rampazzi, V.; Massard, A.; Richard, P.; Picquet, M.; Le Gendre, P.; Hierso, J.-C. ChemCatChem 2012, 4, 1828 1835.

13) Massard, A.; Rampazzi, V.; Perrier, A.; Bodio, E.; Picquet, M.; Richard, P.; Hierso, J.-C.; Le Gendre, P. Organometallics 2012, 31, 947-958.

14) Perrier, A.; Comte, V.; Moïse, C.; Richard, P.; Le Gendre, P. Eur. J. Org. Chem. 2010, 1562-1568.

15) (a) Elsegood, M. R. J.; Smith, M. B.; Sanchez-Ballester, N. M. Acta Crystallogr. Sect. E 2006, 62, m2838-m2840. (b) Lee, J. P.; Hankins, M. J.; Riner, A. D.; Albu, T. V. J. Coord. Chem. 2016, 69, 20-38.

16) Major, Q.; Lough, A. J.; Gusev, D. G. Organometallics 2005, 24 , 2492-2501.

17) Simpson, P. V.; Brown, D. H.; Skelton, B. W.; White, A. H.; Baker, M. V. Organometallics 2015, 34, 2508-2514 
18) $\mathrm{CCl}_{4}$ does not react with conjugated dienes in the presence of (arene) $\mathrm{Cr}(\mathrm{CO})_{3}$ : Gandolfi, O.; Cais, M. J. Organomet. Chem. 1977, 125, 141-154.

19) Benett, M., A.; Huang, T., N.; Matheson, T., W., Smith, A., K. Inorg. Synth. 1982, 21, 74-78.

20) Therrien, B.; Ward, T. W.; Pilkington, M.; Hoffmann, C.; Gilardoni, F.; Weber, J. Organometallics, 1998, 17, 330-337.

21) Dolomanov, O. V.; Bourhis, L. J.; Gildea, R. J; Howard, J. A. K.; Puschmann, H. J. Appl. Cryst. 2009, 42, 339-341.

22) Sheldrick, G. M. Acta Cryst. 2015, A71, 3-8.

23) Sheldrick, G. M. Acta Cryst. 2008, A64, 3-8.

24) Gaussian 09, Revision E.01, Frisch, M. J.; Trucks, G. W.; Schlegel, H. B.; Scuseria, G. E.; Robb, M. A.; Cheeseman, J. R.; Scalmani, G.; Barone, V.; Mennucci, B.; Petersson, G. A.; Nakatsuji, H.; Caricato, M.; Li, X.; Hratchian, H. P.; Izmaylov, A. F.; Bloino, J.; Zheng, G.; Sonnenberg, J. L.; Hada, M.; Ehara, M.; Toyota, K.; Fukuda, R.; Hasegawa, J.; Ishida, M.; Nakajima, T.; Honda, Y.; Kitao, O.; Nakai, H.; Vreven, T.; Montgomery, J. A., Jr.; Peralta, J. E.; Ogliaro, F.; Bearpark, M.; Heyd, J. J.; Brothers, E.; Kudin, K. N.; Staroverov, V. N.; Kobayashi, R.; Normand, J.; Raghavachari, K.; Rendell, A.; Burant, J. C.; Iyengar, S. S.; Tomasi, J.; Cossi, M.; Rega, N.; Millam, J. M.; Klene, M.; Knox, J. E.; Cross, J. B.; Bakken, V.; Adamo, C.; Jaramillo, J.; Gomperts, R.; Stratmann, R. E.; Yazyev, O.; Austin, A. J.; Cammi, R.; Pomelli, C.; Ochterski, J. W.; Martin, R. L.; Morokuma, K.; Zakrzewski, V. G.; Voth, G. A.; Salvador, P.; Dannenberg, J. J.; Dapprich, S.; Daniels, A. D.; Farkas, Ö.; Foresman, J.
B.; Ortiz, J. V.; Cioslowski, J.; Fox, D. J. Gaussian, Inc., Wallingford CT, 2013. 25) Hay, P. J.; Wadt, W. R. J. Chem. Phys. 1985, 82, 270284.

26) Dunning, T. H. Jr.; Hay, P. J. Gaussian basis sets for molecular calculations. In Modern Theoretical Chemistry; Schaefer, H. F. III. Ed.; Plenum: New York, 1977; Vol. 3, pp 1-28.

27) Wadt, W. R.; Hay, P. J. J. Chem Phys. 1985, 82, 284-298.

28) Hay, P. J.; Wadt, W. R. J. Chem . Phys. 1985, 82, 299-310.

29) Adamo C., Barone, V. J. Chem. Phys. 1999, 110, 6158-6170.

30) Le Bahers, T.; Brémond, E.; Ciofini, I.; Adamo, C. Phys. Chem. Chem. Phys. 2014, 16 (28), 14435.

31) Tomasi, J.; Mennucci, B.; Cammi, R.. Chem. Rev. 2005, 105, 2999-3093.

32) Mennucci, B.; Tomasi, J.; Cammi, R.; Cheeseman, J. R.; Frisch, M. J.; Devlin, F. J.; Gabriel, S.; Stephens, P. J. J. Phys. Chem. A 2002, 106, 6102-6113.

33) Andrienko, G. http://www.chemcraftprog.com. Last visited 17/11/2017.

34) Martin, R. L. J. Chem. Phys. 2003, 118, 4775-4777.

35) (a) Feller D. J Comp Chem. 1996, 17, 1571. (b) Schuchardt, K. L.; Didier, B. T.; Elsethagen, T.; Sun, L.; Gurumoorthi, V.; Chase, J.; Li, J.; Windus T. L. J Chem Inf Model 2007, 47, 1045. (c) https://bse.pnl.gov/bse/portal. Last visited 17/11/2017.

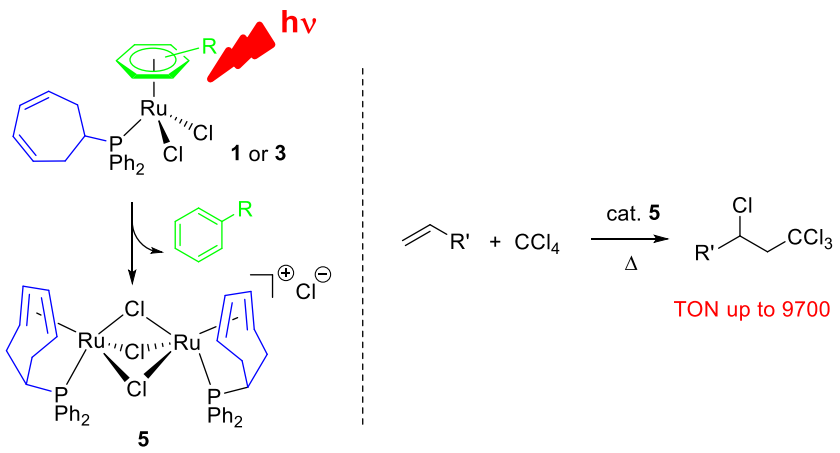

Table of Contents artwork 